\title{
MASTeK
}

$\mathrm{DOE} / \mathrm{NE}-0009$

UC-13, 80

\section{Power Plant Capital Investment Cost Estimates: Current Trends and Sensitivity to Economic Parameters}

October 1979

Published June 1980

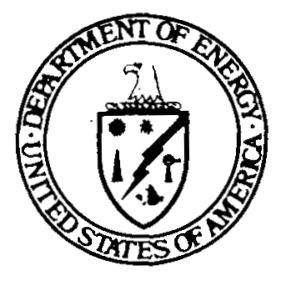

Prepared by:

Oak Ridge National Laboratory and

United Engineers and Constructors Inc.

Published by:

U.S. Department of Energy

Assistant Secretary for Nuclear Energy

Office of Nuclear Reactor Programs

Washington, D.C. 20585

This document is
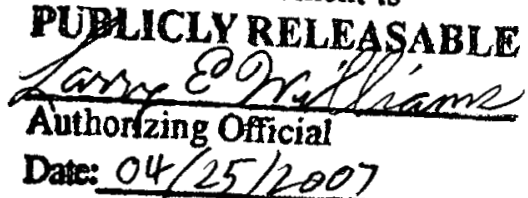


\section{DISCLAIMER}

This report was prepared as an account of work sponsored by an agency of the United States Government. Neither the United States Government nor any agency Thereof, nor any of their employees, makes any warranty, express or implied, or assumes any legal liability or responsibility for the accuracy, completeness, or usefulness of any information, apparatus, product, or process disclosed, or represents that its use would not infringe privately owned rights. Reference herein to any specific commercial product, process, or service by trade name, trademark, manufacturer, or otherwise does not necessarily constitute or imply its endorsement, recommendation, or favoring by the United States Government or any agency thereof. The views and opinions of authors expressed herein do not necessarily state or reflect those of the United States Government or any agency thereof. 


\section{DISCLAIMER}

Portions of this document may be illegible in electronic image products. Images are produced from the best available original document. 



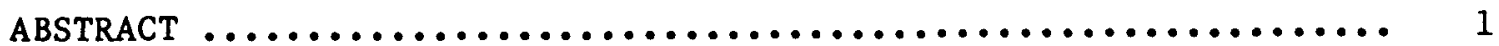

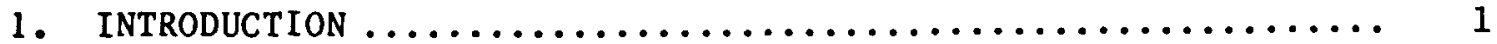

2. REVIEW OF AEC/ERDA/DOE CAPITAL INVESTMENT COST STUDIES -

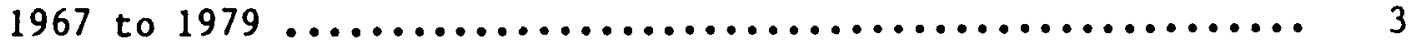

2.1 Report WASH-1082 .......................... 3

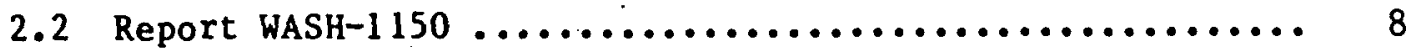

2.3 Report WASH-1230 .......................... 9

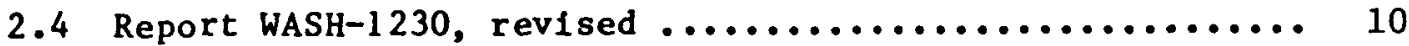



2.6 Report WASH-1345, revised .................... 12

2.7 Reports NUREG-0241 through NUREG-0248 .............. 12

2.8 Energy Economic Data Base ..................... 13

2.9 Continuing Studies .......................... 15

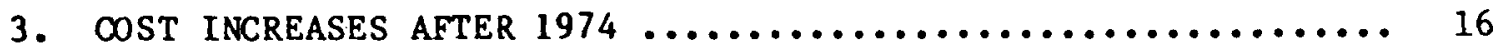

3.1 Effect of Environmental and Safety Requirements on Nuc lear Plants .............................. 16

3.2 Impact of Environmental Requirements for Fossil Plants .. 19

3.3 Miscellaneous Cost Increases .................... 20

3.4 Future Cost Uncertainties ..................... 21

4. THE CONCEPT CODE ............................... 23

5. PLANT CAPITAL INVESTMENT COST ESTIMATES USING CONCEPT ...... 30

6. Cost SEnSITIVITY STUdies $\ldots \ldots \ldots \ldots \ldots \ldots \ldots \ldots \ldots \ldots \ldots \ldots \ldots \ldots \ldots . \ldots \ldots$

6.1 Unte Size ................................. 41

6.2 Construction Labor $\ldots \ldots \ldots \ldots \ldots \ldots \ldots \ldots \ldots \ldots \ldots \ldots . \ldots . \ldots . \ldots$

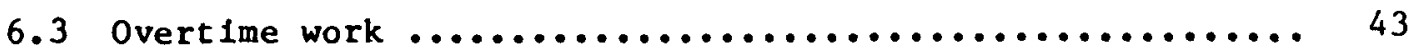

6.4 Lead Time $\ldots \ldots \ldots \ldots \ldots \ldots \ldots \ldots \ldots \ldots \ldots \ldots \ldots \ldots \ldots \ldots \ldots \ldots . \ldots \ldots$

6.5 Escalation .................................. 49

6.6 Interest During Construction ................... 52

6.7 Reglonal Variations .......................... 52

7. REFERENCES $\ldots \ldots \ldots \ldots \ldots \ldots \ldots \ldots \ldots \ldots \ldots \ldots \ldots \ldots \ldots \ldots \ldots \ldots \ldots \ldots \ldots$ 
POWER PLANT CAPITAL INVESTMENT COST ESTIMATES - CURRENT TRENDS AND SENSITIVITY TO ECONOMIC PARAMETERS

\section{ABSTRACT}

Th1s report describes power plant capttal investment cost studies that were carried out as part of the activities of the Plans and Analysis Division, Office of Nuclear Energy Programs, U.S. Department of Energy. The activities include investment cost studies prepared by an architect-engineer, including trends, effects of environmental and safety requirements, and construction schedules. A computer code used to prepare capital investment cost estimates under varying economic conditions is described, and application of this code is demonstrated by sensitivity studies.

Key Words: capital investment cost, power plant costs, power costs, construction costs, power plant economics

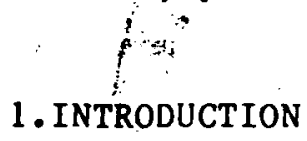

This report describes studies that have been carried out as part of the activities of the Plans and Analysis Division, Office of Nuclear Energy Programs, U.S. Department of Energy, for the purpose of investigating the capital investment costs of nuclear and coal-fueled steamelectric power plants. These activitles include reference plant investment cost studies, development of computer codes, and studies of cost sensitivity to changing technical and economic parameters.

Program planning in DOE requires future projections of power plant costs that are consistent with current market prices and regulatory climate, that accurately reflect the anticipated changes in economic conditions, and that are easily obtained by the planner. In generating these projections for program planning activities, it became apparent that improved procedures, including a standardized fornat for reporting capital investment costs, were needed for rapid updating of cost projections as technical, economic, and regulatory conditions change.

Estimation of major equipment prices and plant construction costs for a power station ten years or more in advance of required avaliability for service is obviously subject to considerable uncertainty. Even 
in a stable economy of predictable labor and equipment costs, significant cost variables would remain, such as utility procurement practices, local construction and skilled labor rates, technical, environmental, and economic factors related to the particular site, and the utility's financial structure. All these factors would necessarily require careful assessment for purposes of detalled capltal investment cost est1mates. Highly varlable labor and material escalation rates, basic inflationary economic trends, and changing safety and environmental regulations experienced in recent years all contribute to the difficulty of making accurate Investment cost projections for power stations.

The need to keep abreast of the capital investment costs of nuclear and coal-fired power plants and to identify the reasons for increases in costs resulted in a series of investment cost studies performed by United Engineers \& Constructors Inc. (UE $\&$ ) under contract to the DOE and 1ts predecessors. In the course of these studies, much valuable information has been accumulated on cost trends, cost effects of environmental and safety requirements, and construction schedules. This information is reviewed and discussed.

In addition, the need to produce rational and consistent Investment cost estimates for various locations and time periods has led to the development of a computer program at the Oak Ridge National Laboratory (ORNL) that will prepare conceptual-type cost estimates for a selected set of input parameters. The computer code ut1lizes reférence plant investment cost estimates as a starting basis for developing estimates for particular conditions of plant size, location, and startup date. The reference investment cost estimates are based on the series of Investment cost studies prepared by UE\&C as mentioned above. The report also presents the results of a cost sensitivity study that was made with this code. 


\section{REVIEW OF AEC/ERDA/DOE CAPITAL INVESTMENT COST STUDIES - 1967 to 1979}

The results of the investment cost studies performed by UE\&C a re shown graphically in F1gs. 2.1 and 2.2. Estimated costs for 11ght-water reactor (LWR) nuclear power generating stations (NPGS) 1ncreased as shown in Fig. 2.1 from about $\$ 134 / \mathrm{kW}(\mathrm{e})$ in 1967 (for 1973 operation) to over $\$ 700 / \mathrm{kW}(e)$ in 1974 (for 1983 operation) and to over $\$ 1500 / \mathrm{kW}(\mathrm{e})$ in 1978 (for 1988 operation). Figure 2.3 shows how the elements making up these total costs have shifted. Although total costs have risen, the share of the cost attributable to the nuclear steam supply system (NSSS) plus the turbine-generator dropped from about 40 percent in 1967 to 15 percent in 1974 and to only elght percent in 1978. Conversely, the cost of escalation plus allowance for funds used during construction (AFUDC) increased from 17 percent in 1967 to almost 40 percent in 1974 and over 55 percent in 1978. Clearly, the pressure to reduce costs continues to remain on time-related factors instead of hardware.

Estimated costs for fossil-fired power generating stations (FPGS) increased as shown in Fig. 2.2 from $\$ 110 / \mathrm{kW}(\mathrm{e})$ in 1967 (for 1973 operation) to over $\$ 600 / \mathrm{kW}(e)$ in 1974 (for 1983 operation) and to over $\$ 1050 /$ $\mathrm{kW}(\mathrm{e})$ in 1978 (for 1988 operation).

The ground rules used in these estimates are given in Table 2.1 and the studies are discussed in the following paragraphs. -

\subsection{Report WASH-1082}

The 1967 UE\&C study of light-water reactor (LWR) plant costs was published in 1968 as WASH-1082.1 The capital cost for a 1000-MW(e) LWR plant at the start of the project, in mid-1967 dollar values, was estimated as about $\$ 134 / \mathrm{kW}(\mathrm{e})$, Including allowance for interest during construction but no allowance for escalation. This estimate appeared consistent with published cost estimates for plants announced by utilities at that time: $\$ 124 / \mathrm{kW}(e)$ for Dresden 2 and 3 and $\$ 115 / \mathrm{kW}(e)$ for Browns Ferry 1 and 2. Although these costs were higher than estimated costs for equivalent coal-fired plants, the anticlpated savings in nuclear fuel 


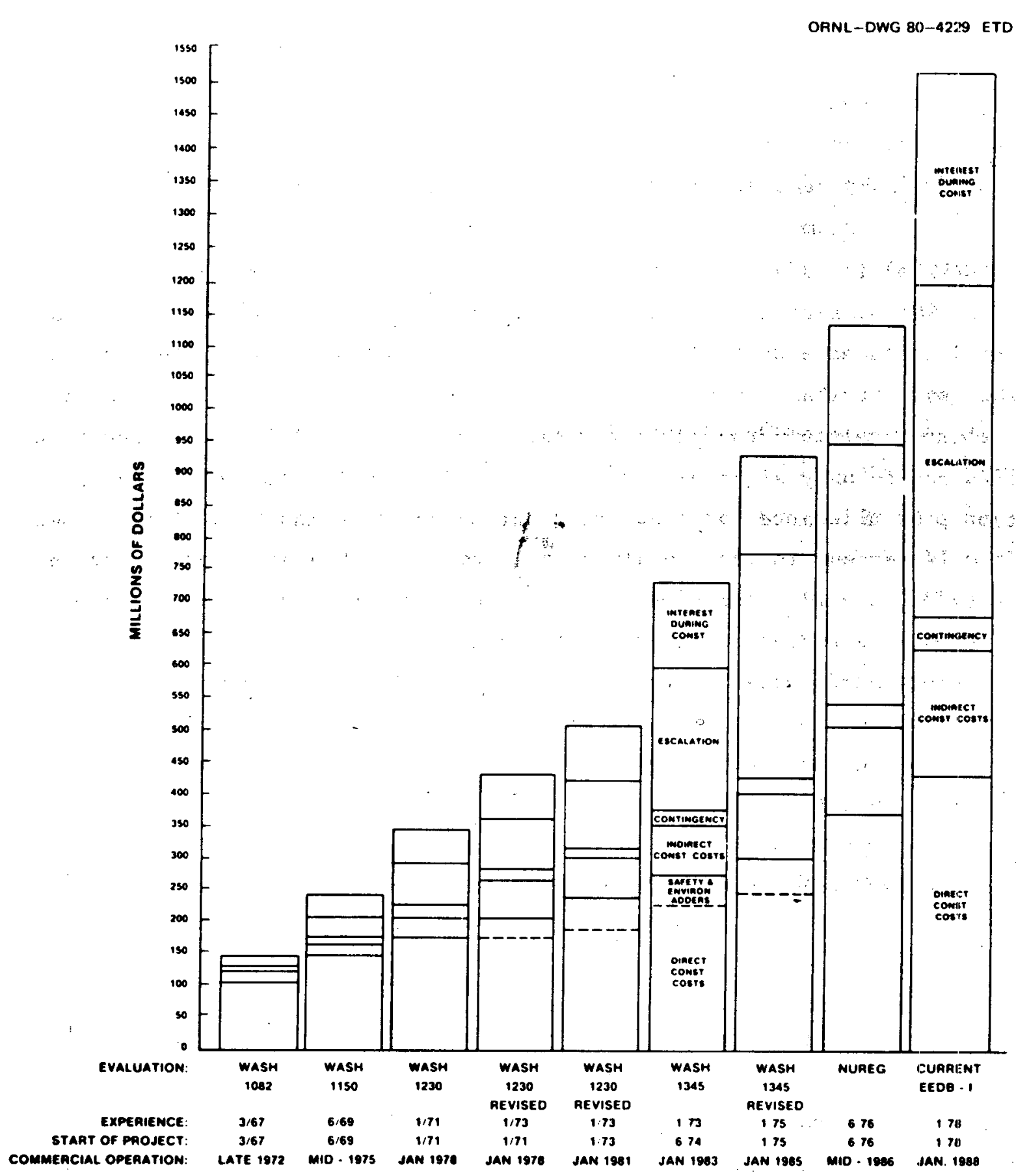

F18. 2.1. Nuclear plant Investment cost estimates for a single 1000-MW(e) 11ght-water moderated reactor plant. 
ORNL-DWG 80-4230 ETD
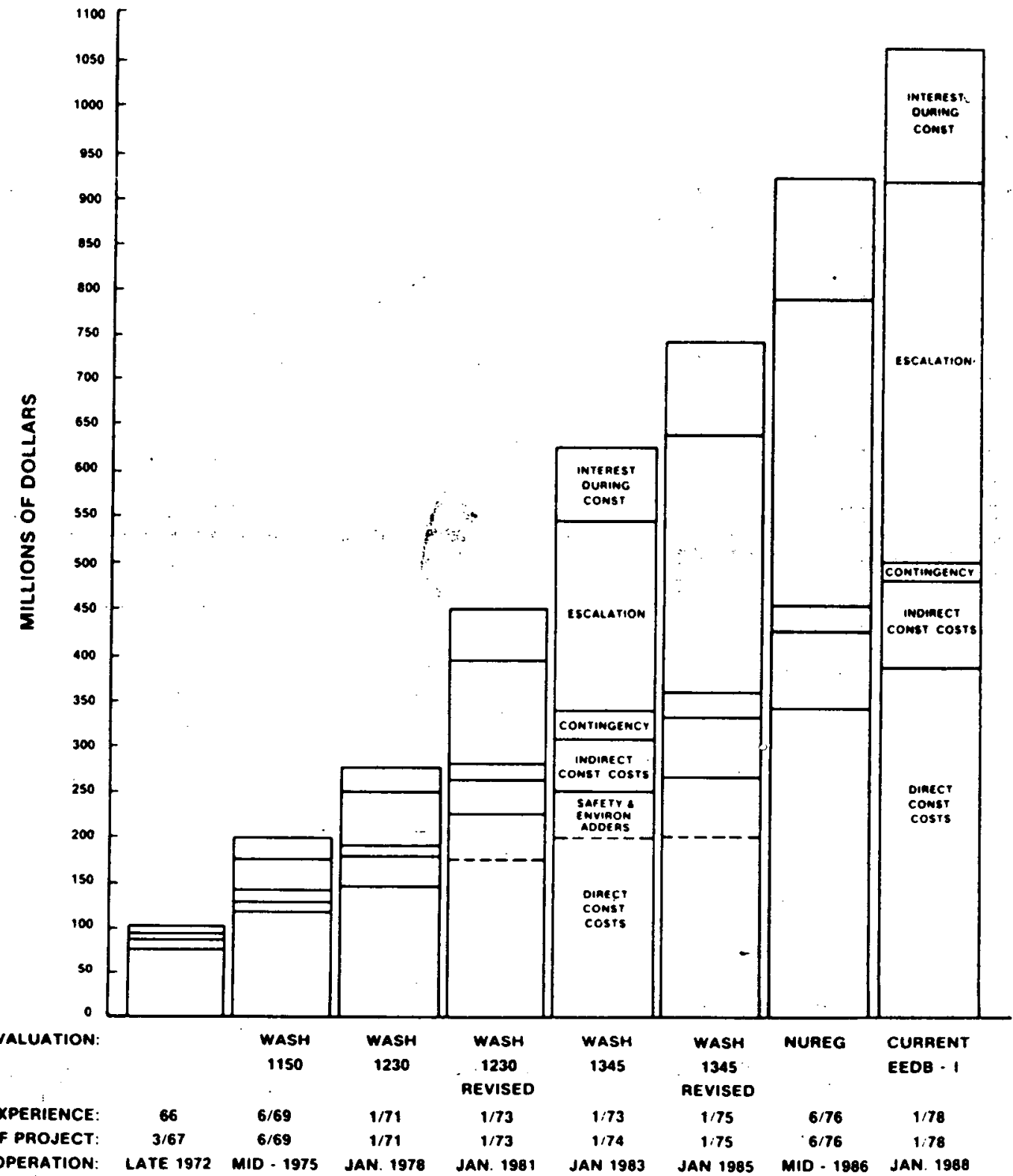

Fig. 2.2. Fos811 plant investment cost estimates for a single 1000-MW(e) coal-fired plant. 


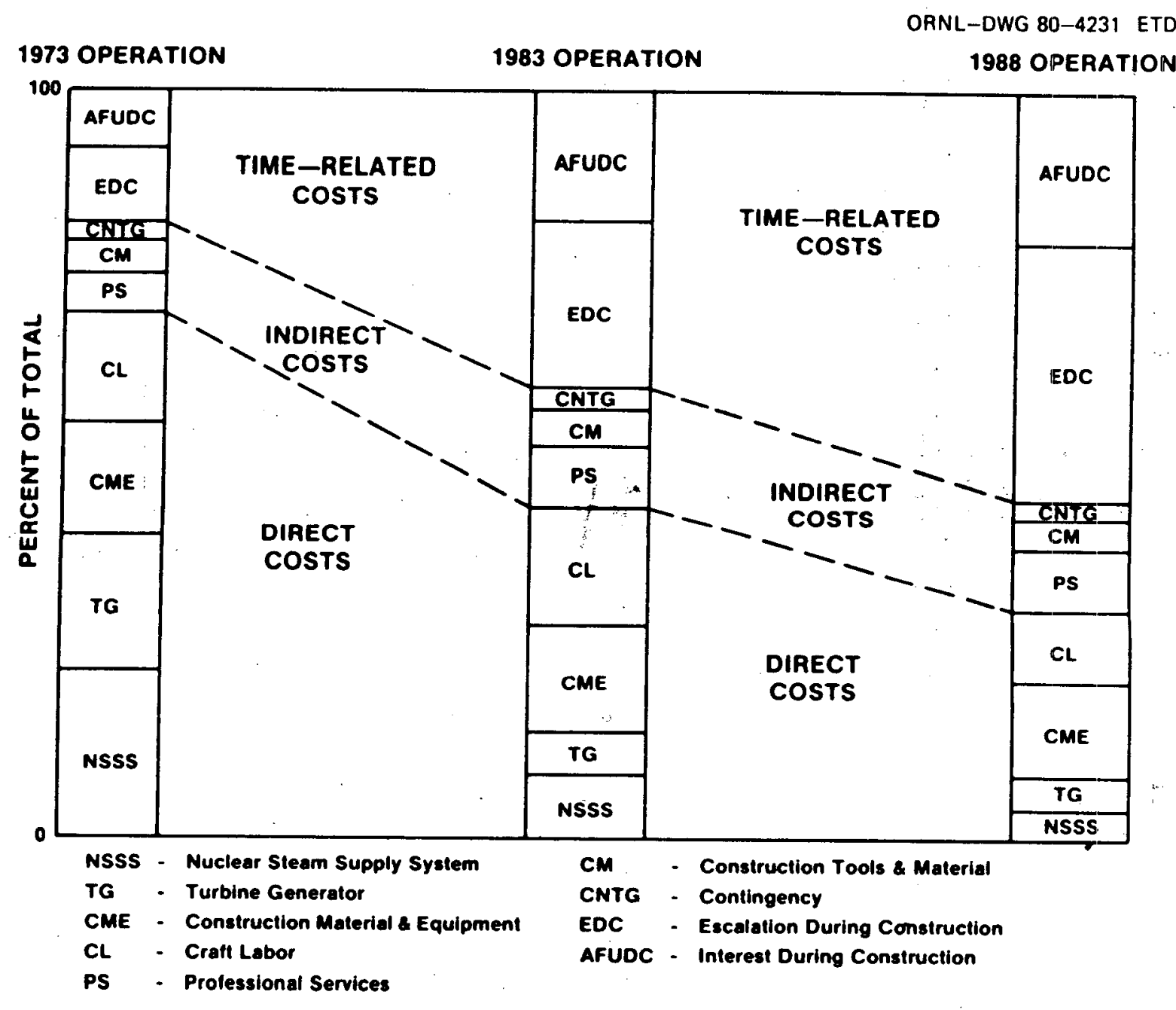

F1g. 2.3. Shifts in distribution of nuclear power plant capital. costs. 
Table 21. Cout-entimating eround rules

\begin{tabular}{|c|c|c|c|c|c|c|c|c|c|c|c|c|c|c|c|}
\hline \multirow{2}{*}{$\begin{array}{c}\text { AEPOAT } \\
\text { 'Sten of Project Detos) }\end{array}$} & \multirow{2}{*}{$\begin{array}{l}\text { WASH-1008 } \\
\text { (Mareh 1907) }\end{array}$} & \multicolumn{2}{|c|}{$\begin{array}{l}\text { WASH-11so } \\
\text { (Jume ISED) }\end{array}$} & \multicolumn{2}{|c|}{$\begin{array}{l}\text { WASH-1230 } \\
\text { (Januery 1971) }\end{array}$} & \multicolumn{2}{|c|}{$\begin{array}{c}\text { WASH-1230 (revibod) } \\
\text { (Januery 1973) }\end{array}$} & \multicolumn{2}{|c|}{$\begin{array}{l}\text { WASH-1345 } \\
\text { (Jury 1974) }\end{array}$} & \multicolumn{2}{|c|}{$\begin{array}{c}\text { WASSH-1345 (revineoc) } \\
\text { (Jamuary 1975) }\end{array}$} & \multicolumn{2}{|c|}{$\begin{array}{l}\text { MUREO } \\
\text { (JuIY 1978) }\end{array}$} & \multicolumn{2}{|c|}{$\begin{array}{c}\text { EEDB-1 } \\
\text { (Jamuerv 1978) }\end{array}$} \\
\hline & & Nuctaer & Foceill & Nuctear" & Focell & Nuctear ${ }^{\circ}$ & Fonell & Nueloer ${ }^{\circ}$ & Fowail & Nucteer ${ }^{\circ}$ & Fonsil & twewered & Fonsil & Nucroese & Fossil \\
\hline $\begin{array}{l}\text { Construction vetrooulio'. months } \\
\text { PSAA/ER preperation }\end{array}$ & - & - & & 6 & & $12 \cdot 10$ & . & $12 \cdot 18$ & 9 & $12 \cdot 24$ & 10 & $15 \cdot 24$ & $10-12$ & 18 & $10-14$ \\
\hline PSARAER review to conetruction Dormith (CP) & $9 \cdot 12$ & $12 \cdot 15$ & & $15 \cdot 10$ & c & $18-21$ & c & $16-21$ & 6 & 24 & 6 & $22 \cdot \mathbf{2 0}$ & 0.0 & $20 \cdot 34$ & $6-10$ \\
\hline Enghneering lased time (toseail) & & & 6 & & e & & - & & & & & & & & \\
\hline Construction perios (1000-anw/o) diant) & 42 & 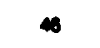 & 41 & $\mathbf{s 4}$ & 4 & is & 4 & $\infty$ & 45 & $\infty$ & ه & $\infty-\infty$ & 40.54 & 72 & $40-54$ \\
\hline Preopermional weating & 6 & 6 & 3 & 6 & 4 & 8 & 4 & 6 & 3 & 6 & 3 & 6 & 3 & 6 & 3 \\
\hline 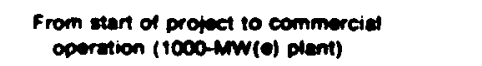 & 60.66 & $70 \cdot 73$ & so & $91 \cdot 04$ & 34 & $\infty-\infty$ & s4 & $20 \cdot 105$ & $\infty$ & $|100 \cdot 114|$ & 67 & $100 \cdot 124$ & $67-\pi 7$ & $124-130$ & $67 \cdot 81$ \\
\hline Comingoncy & 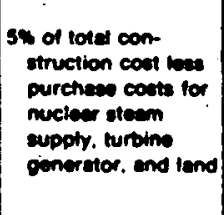 & $\begin{array}{l}\text { 10\% of se } \\
\text { peckesp }\end{array}$ & $\operatorname{coset}$ & $\begin{array}{l}\text { Crath labor } \\
\text { matl. B } \\
\text { protessic } \\
\text { sorvices. } \\
\text { (applied } \\
\text { direct an } \\
\text { costs) }\end{array}$ & 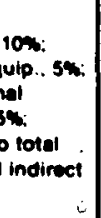 & $\begin{array}{l}\text { Cran labor. } \\
\text { equip.. a } \\
\text { profosaiv } \\
\text { services. } \\
\text { (epplied } \\
\text { direct an } \\
\text { conts) }\end{array}$ & 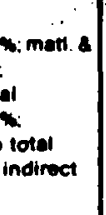 & 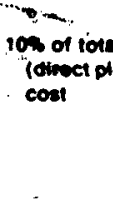 & inotirect) & semo as $w$ & $S H-1345$ & Samean $r$ & ASH+13AS & $\begin{array}{l}\text { Orof total } \\
\text { plus ind }\end{array}$ & $\begin{array}{l}\text { ase (direct } \\
\text { oct) cost }\end{array}$ \\
\hline \multirow[t]{2}{*}{ Excelation during construction } & \multirow[t]{2}{*}{ Not incluodod } & \multicolumn{2}{|c|}{ 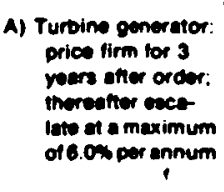 } & \multicolumn{2}{|c|}{$\begin{array}{l}\text { A) Turbine genermor: } \\
\text { samo as WASH } \\
1150\end{array}$} & \multicolumn{2}{|c|}{$\begin{array}{l}\text { A) Turoino generator: } \\
\text { samo as WASH } \\
.1150\end{array}$} & \multicolumn{2}{|c|}{$\begin{array}{l}\text { A) Turbine generator: } \\
\therefore \quad \text { same a WASH } \\
1150\end{array}$} & \multirow{2}{*}{\multicolumn{2}{|c|}{$\begin{array}{l}\text { ow compound interest } \\
\text { on casen now. } \\
\text { inclusing con- } \\
\text { tingoncy }\end{array}$}} & \multirow{2}{*}{\multicolumn{2}{|c|}{$\begin{array}{l}\text { Same eas WASH-1345 } \\
\text { (revisoo) }\end{array}$}} & \multirow{2}{*}{\multicolumn{2}{|c|}{$\begin{array}{l}\text { Same as WASH-1345 } \\
\text { (revisoo) }\end{array}$}} \\
\hline & & \multicolumn{2}{|c|}{$\begin{array}{l}\text { 8) Batunce (inctuding } \\
\text { contingoncy): } \\
\text { oeremmeric groses } \\
\text { eteatution retes of } \\
7.54 \text { por year }\end{array}$} & \multicolumn{2}{|c|}{ 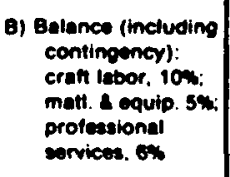 } & \multicolumn{2}{|c|}{ 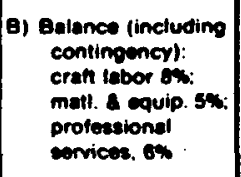 } & \multicolumn{2}{|c|}{$\begin{array}{l}\text { O) (inicluding } \\
\text { contingency): } \\
\text { eraft labor 12.5\%: } \\
\text { metl. \& equip. } \\
20 \% \text { : protesional } \\
\text { senvices 12.2\% }\end{array}$} & & & & & & \\
\hline Interest during construction & $\begin{array}{l}\text { 5.0\% simple intoront } \\
\text { appliod to TID-7025 } \\
\text { casen flow }\end{array}$ & \multicolumn{2}{|c|}{$\begin{array}{l}\text { 6.54 simple interest } \\
\text { appliod to a typical } \\
\text { ceas llow, including } \\
\text { eacalation }\end{array}$} & \multicolumn{2}{|c|}{$\begin{array}{l}\text { 7.5\% simple interest } \\
\text { on cash now. } \\
\text { including escaletion }\end{array}$} & \multicolumn{2}{|c|}{$\begin{array}{l}7.5 \% \text { simple interest } \\
\text { on cash fiow. } \\
\text { including escalation }\end{array}$} & \multicolumn{2}{|c|}{$\begin{array}{l}\text { ow compound interest } \\
\text { on cash flow. } \\
\text { including escalation }\end{array}$} & \multicolumn{2}{|c|}{ Some as WASH-134S } & \multicolumn{2}{|c|}{ Same ea WASH-1345 } & \multicolumn{2}{|c|}{ Same as WASH-1345 } \\
\hline
\end{tabular}

- Environmented report (ER) subminted simuteneousty with preliminary saftety analysis review (PSAR) ER Echeduled dors

Allowance for ER. Envronmented Protection Agency (EPA) Dermits, and review - 181024 months.

d Estimatod. no nuclear plents committed in 1978 
costs indicated that nuclear plants would be competitive with coal. plants burning coal at $25 \$ / \mathrm{MBtu}$.

A climate of general optimism prevailed, and it was belleved that the nuclear industry had at last reached its goal of low-cost electrictey from nuclear power plants. However, the optimistic view was soon to be severely challenged, because reported estimated costs began to increase sharply. Furthermore, there was little consistency between reported costs for different plants of the same type, size, and timing. Thus, the cost estimates reported in WASH-1082 we re quickly shown to be unrealistically low, and additional studies were initiated to obtain more definitive estimates and to account for the increases.

\subsection{Report WASH-1150}

During $1968^{\prime}$ and 1969 , UE\&C made series of studies for the AEC. Consistent engineering and cost estimate ground rules were carefully defined to obtain a fair comparison between nuclear and fossil-fueled plant costs. Also, much effort was devoted to determining causes of the unexpected cost increases, Identifying continuing trends in plant costs, and projecting future costs. These studies were published in May 1970 as WASH-1 150.2

The estimated cost for a 1000-MW(e) LWR plant initiated in mid-1969 for mid-1975 operation was about $\$ 240 / \mathrm{kW}(\mathrm{e})$, and that for a $1000-\mathrm{MW}(\mathrm{e})$ coal-fired unit entering service in mid-1975 was about $\$ 195 / \mathrm{kW}(e)$. Based on a total power cost comparison, the estimated break-even coal cost was $26 \$ / M B t u$. Thus, it was concluded that, even though power plant capital costs had risen sharply, nuclear plants still appeared to be econonically competitive with fossil-fueled plants in many areas of the United States.

Results of the UE\&C work Identified the following dominant factors that had increased estimated plant costs since WASH-1082 was published:

1. more complete definition of the bill of materials and scope of work than was included in early estimates;

2. requirements for higher quality of equipment, materials, and workma nship; 
3. higher unit costs for equipment, materials, and labor;

4. addition of supplementary systems to enhance safety;

5. increased engineering and construction management costs due to added features, higher quality standards, more detalled licensing procedures, longer construction schedules, and increases in design and management salarles;

6. Increased interest charges due to increases in direct costs, longer. construction schedules, and higher interest rates;

7. effects of escalation during construction that were not included in early estimates and that can be a large amount in an inflationary economy. Current practice is to include escalation during construction in the cost estimate;

8. the trend away from curn-key contracts. Since some of these factors infolved changes that were still in progress, their ultimate cost impact was difficult to estimate. Further, the potential impact of future additional requirements increased the uncertainty in projected cost estimates. Therefore, the AEC requested that UE\&C provide more detalled cost estimates for various types of power plants. These detailed cost estimates were to serve as a reference point for projections and also as cost models for capital cost computer codes being developed concurrently at ORNL.

\subsection{Report WASH-1230}

This request for detailed cost estimates resulted in further work by UE\&C under contract to the AEC. The scope included preparation of cost estimates using six-digit levels of the AEC code-of-accounts format ${ }^{3}$ for four plant types: pressurized-water reactor (PWR), bolling-water reactor (BWR), coal-fired plants, and o11-fired plants. The results from this effort were published in June 1972 as WASH-1 230.4-7

This study utilized design features typical of plants under construction In early 1971; for example, features of Dresden 2 and 3 for the BWR and Indian Point 2 and 3 for the PWR. These design features were 
adjusted to (1) identify and add costs for the latest safety requirements, codes, and standards current at the time, (2) include environmental protection and 11censing criteria applicable at the time, and (3) reflect then-current market conditions and cost data. This study did not include product line Improvements, such as the BWR design BWR/6 and MarkIII contalnment and the 1ce-condenser contalnment for the PWR. In add1tion, the study did not completely anticlpate the current safety and environmental requirements.

Based on these studies, capital costs (including contingency and interest and escalation during construction) for 1000-MW(e) plants entering. service in late 1977 were estimated as $\$ 345 / \mathrm{kW}(e)$ for LWRs and $\$ 275 / \mathrm{kW}(\mathrm{e})$ for coal-fired plants.

\subsection{Report WASH-1230, Revised}

Although the studies reported in WASH-1230 involved a major effort to identify all cost elements and include their effects in the detailed cost estimates, increases in reported power plant costs continued to outpace expectations. Essentlally all power plants under construction began to show large cost overruns relative to thelr initial cost estimates. Again, UE\&C was asked to identify the causes of the cost overruns. In the course of this work, the WASH-1230 studies were reviewed, and the cost estimates were revised to reflect plant design and environmental requirements applicable in early 1973. As shown in Fig. 2.1, these revisions led to cost estimates of about $\$ 440$ and $\$ 500 / \mathrm{kW}(e)$ for $1000-\mathrm{MW}(\mathrm{e})$ LWRs scheduled for service in 1978 and 1981 respectively.

The principal factors contributing to this increase over the 1971 estimate of $\$ 345 / \mathrm{kW}(e)$ for a plant entering service in 1978 are as follows:

1. additional cost escalation from 1978 to 1981 ;

2. AEC/DRL requirements for additional engineering and safety features affecting plant design;

3. AEC/EPA requirements for environmental considerations in plant design and analysis; 
4. Increased englneering, management, labor, equipment, and material costs as a result of the above additional plant features and design requi rements;

5. longer construction schedules due to the fncreasing detall and complexity of plant construction permit and licensing stages;

6. Increased escalation and interest costs due to the longer design and construction schedules.

As shown in Fig. 2.2, the estimate for 1000-MW(e) coal-fired plants scheduled for 1981 operation, $\$ 450 / \mathrm{kW}(e)$, is about one and one-half times that for 1978 operation, an increase comparable to that projected at that time for nuclear plants. The reasons for the increases in the costs. for coal-fired plants are similar to those for nuclear plants: escalation of costs for labor, materials, and equipment and additional plant requirements imposed by environmental standards and regulations.

\subsection{Report WASH-1345}

The work described in Sections 2.1 through 2.4 above reflects the results of the referenced formalized studies made through January 1973. This work was summarized in 1974 as. WASH-1345.8 The summary also included a description of related ongoing studies.

For the period January 1973 through mid-1974, escalation trends continued but shifted in emphasis from field labor to mánufactured products and basic materials.

Escalation in field labor costs declined during this 18 month period from the double-digit inflation rates of the previous several years to approximately elght percent per year. During this same period, the escalation rate for ut1lity related basic materials and manufactured goods rose to about 13 percent per year.

The results of the studies referenced above, which reflect January 1973 direct costs and assumed operation in 1981, do not account for the rap1d inflation of the 18 months preceding June 1974. Additionally, they do not reflect the $s$ chedule restraints which delayed a unit being planned in late 1974 from a 1981-startup to a 1983-startup. 
Revisions made to the 1981-startup plant estimates to provide for the intensive escalation of the 18 months previous to June 1974 and for a 1983-startup led to the costs of 1000-MW(e) plants of about $\$ 720 / \mathrm{kW}(\mathrm{e})$ for a nuclear plant and $\$ 625 / \mathrm{kW}(\mathrm{e})$ for a coal-fired plant.

\subsection{Report WASH-1345, Revised}

During 1975, new nuclear and coal-fired plant cost estimates were developed by UE\&C for use in ongoing studies as alternatives for compar18on. These estlmates Indicated that both coal and nuclear plant costs we re continuing to rise sharply. Section 3 discusses the driving factors behind the cost increases that occurred during and following 1975.

Based on these interim revisions to the cost studies, capital costs (Including contingency and Interest and escalation during construction) for 1000-MW(e) plants entering service 1 h 1985 we re estimated as $\$ 925$ $\mathrm{kW}(\mathrm{e}$; for LWRs and $\$ 750 / \mathrm{kW}(\mathrm{e})$ for coal-fired plants.

\subsection{Reports NUREG-0241 through NUREG-0244}

UE\&C was requested to prepare detalled cost estimates jolntly by the U.S. Energy Research and Development Administration and the U.S. Nuclear Regulatory Commission. The scope included preparation of cost estimates using the UE\&C nine-digit level expansion of the AEC code-of-accounts format and a detalled equipment list for four plant types: " pressurlizedwater reactor (PWR), bolling-water reactor (BWR), and 800-MW(e) and 1200MW(e) high sulfur and low sulfur coal-fired power plants. The results from this effort were published in 1977 as NUREG 0241 through 0244," Commercial Electric Power Cost Studies."9-12 In addition, cost studies were prepared for multiple-unit plants, fuel supply facilities, alternate cooling systems, and total generating costs for PWR, BWR, and coal-f 1 red plants13-16 and capital investment costs estimates for pressurized heavy water reactor (PHWR) and gas-cooled fast reactor (GCFR) nuclear. plants. 17,18

These studies utilized design features typical of plants under construction in early 1976; for example, features of Seabrook for the PWR 


$$
13
$$

and the General Electric Technical Reference Plant Design for the BWR. A standard, hypothetical "Middletown" site and a full complement of 11censIng and design criteria, circa January 1, 19.76, we re ut1lized.

The coal-fired power plants incorporate a once-through supercritical pressure single reheat type steam generator to supply steam to a crosscompound elght-flow turbine for the larger units. A difference in net plant output between the high sulfur coal (HSC) plant and the lower sulfur coal (LSC) plant is due to the variation in scrubber auxillary power requirements. The HSC plants are designed to burn Eastern Bitumi nous coal with a 3.61 percent sulfur content, whlle the LSC plants burn Western Sub-Bitumimous coal with 0.5 percent sulfur content. These studies produced the following capital costs (excluding contingency and interest and escalation during construction) based on prices effective as of July 1,1976 :

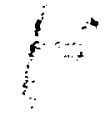

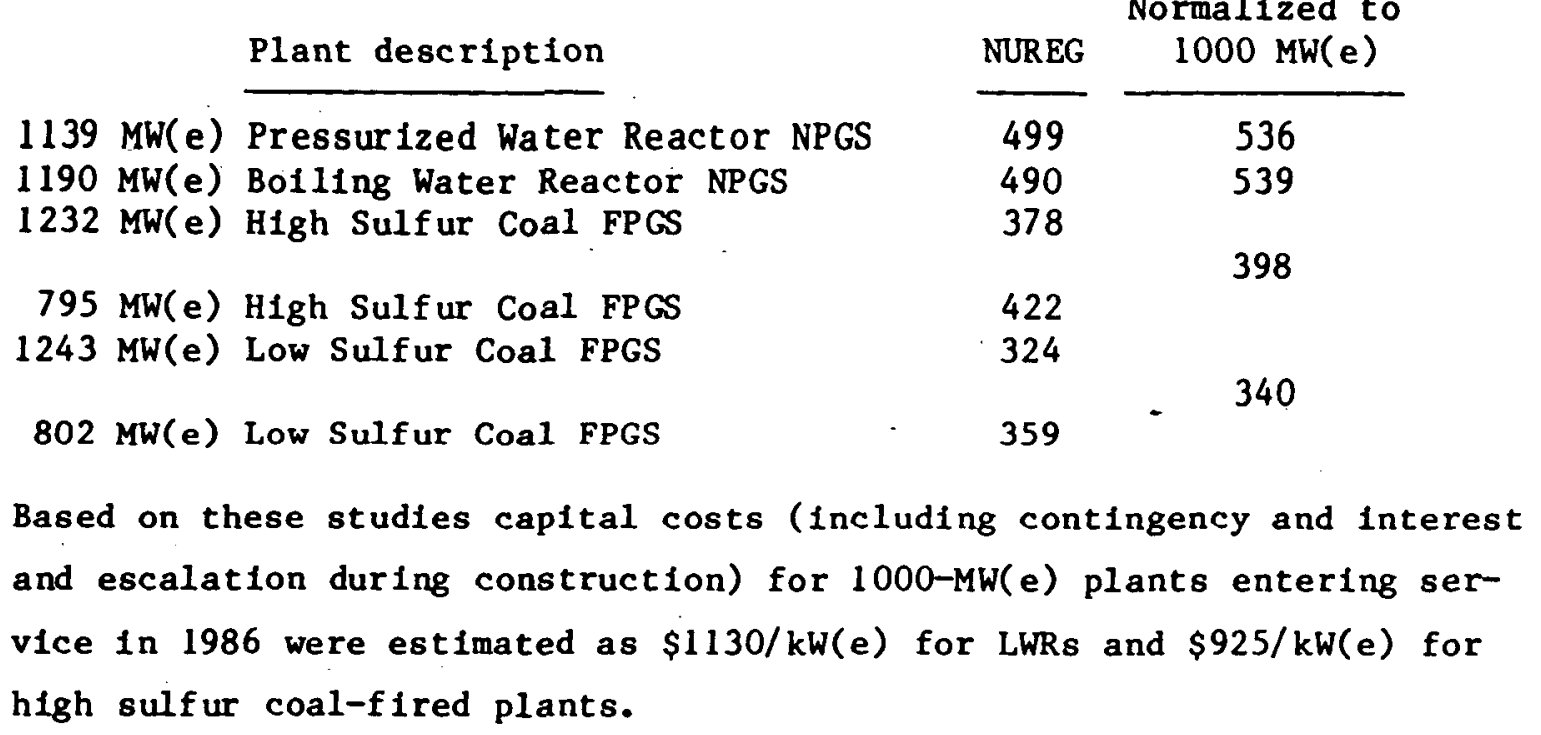

\subsection{Report Energy Economic Data Base}

During FY 1978; UE\&C assembled the Energy Economic Data Base (EEDB) for the Department of Energy (DOE). The objective. of the EEDB Program 
was to provide periodic updates of consistent technical and cost information of significance to DOE in planning U.S. civilian nuclear power programs and in evaluating the nuclear option against alternatives. The effective cost and regulation date for Phase I of EEDB is January 1, 1978.

The EEDB currently contains technical and capital cost information. for six nuclear and six alternative power generating stations: PWR, PHWR, BWR, GCFR, 2-HSC, 2-LSC, HTGR (High Temperature Gas Cooled Reactor), LMFBR (Liquid Metal Fast Breeder Reactor), CGCC (Coal Gasification Combined Cycle Plant), CLIQ (Coal Liquefaction Plant). Costs are based upon complete conceptual designs for a single unit, steam electric power generating station located on the standard, hypothetical "Middletown" site. However, the technical and econonic data vary in degree of detail for the newer concepts, and rellability of the estimates also varies with the available detall. Technical detafls and capital costs are evolutionary from the NUREG series of studies described in Section 2.7 above and other studies by General Atomic Company (HTGR), Combustion Engineering, Inc. (LMFBR and CGCC), and Gulf Mineral Resources Company (CLIQ). Capacities of the plants for which conceptual designs and capital costs were developed varied because of the evolutionary nature of the data base. A significant cost change. was introduced for all plants in the doubling of the engineering account in the indirect costs to reflect industry awareness that these costs were being estimated at too low a level. The EEDB yielded the following capital costs (excluding contingency and interest and escalation during construction) based on prices in effect on Ja nuary 1, 1978:

Plant description

1190 MW(e) Bolling Water Reactor NPGS

1139 MW(e) Pressurfzed Water Reactor NPGS

1232 MW(e) H1gh Sulfur Coal FPGS

795 MW(e) High Sulfur Coal FPGS

1243 MW(e) Low Sulfur Coal FPGS

802 MW(e) Low Sulfur Coal FPGS
Capital cost $\$ / \mathrm{kW}(\mathrm{e})$

\begin{tabular}{cc}
\hline EEDB & $\begin{array}{c}\text { No rmalized to } \\
1000 \text { MW(e) }\end{array}$ \\
571 & 628 \\
581 & 624 \\
424 & \\
465 & 443 \\
364 & \\
399 & 380
\end{tabular}


Based on this information, capital costs (including contingency and Interest and escalation during construction) for 1000-MW(e) plants entering service in 1988, were estimated as $\$ 1500 / \mathrm{kW}(\mathrm{e})$ for LWRs and $\$ 1050 / \mathrm{kW}(\mathrm{e})$ for high sulfur coal-fired plants.

\subsection{Continuing Studies}

Continuing during FY 1979 and FY 1980, the EEDB w1ll be updated and expanded as required to effectively meet the DOE objectives. For FY 1979, the effective cost and regulation date of the update has been advanced to January 1, 1979. For FY 1980, the effective cost and regulation date of the update will be advanced to January 1, 1980. Technical impact for the nuclear plants will be small for the 1/1/79 update. How ever, the 1977 emission requirements, which became effective during 1979, are being evaluated for implementation on the coal plant alternatives. This will include the addition of scrubbers to the low sulfur coal plants. Necessary minor improvements are being made in the accuracy of all plant models, and capital and labor cost escalation from $1 / 1 / 78$ to $1 / 1 / 79$ and labor productivity adjustments are being incorporated.

It is expected that initial regulatory and technical improvements in response to the Three Mile Island incident will be incorporated in the nuclear plant cost estimates for the 1/1/80 update. Technical details and refined costs will be included for the coal plant alternatives in response to industry experfence with the 1977 emission requirements implemented in 1979. Labor productivity will be evaluated to determine if recent indications signal a trend to productivity falloff. 


\section{COST INCREASES AFTER 1974}

Report WASH-1345 discussed the cost increase drivers affecting capital costs of nuclear and fossil power generating stations through 1974 . Driving factors behind the cost increases that occurred during and following 1975 are discussed in this section. WASH-1345 identified specif1c cost adders developed to explain rising plant costs. The NUREG and EEDB cost studies, discussed in Sect. 2, have incorporated the Impact of the previously unrecognized cost drivers in the cost estimates of the system, structure, and component level. Consequently, costs generated by this impact on design are no longer readily obtatnable. The follow Ing discussion will, therefore, treat this subject in a qualitative'way. To a large extent, the most significant contributors to the 1ncreases in U.S. power plant construction costs and, therefore, total generating costs, are more stringent and greater quantities of regulations, codes, and standards, which must be satisfled. Other driving factors are increasing design and eng1neering manhours, increasing quantities of materials, and increasing construction manhours," all of which ultimately result in delay of overall schedules. Construction schedules have been further delayed by an increasing time required to obtain regulatory approval and by an increasing number of local, state, and federal agencies, whlch are required to give their approval. There is also an Increasing number of outside agencies and individuals participating in the regulatory process. Interest and escalation during construction are directly dependent on plant construction schedules and have been rising at significant rates. For example, in 1978, a one-year schedule extension for a two-unit, 2000-MW(e) nuclear power generating station added $\$ 170 \times 10^{6}$ in escalation and interest costs.

\subsection{Effect of Environmental and Safety Requirements on Nuclear Plants}

The number of standards for nuclear applications has grown exponentially for a decade, with a very steep rise from 1973 to 1977. Although this growth shown in Fig. 3.1 has begun to level of $f$, the full impact of 


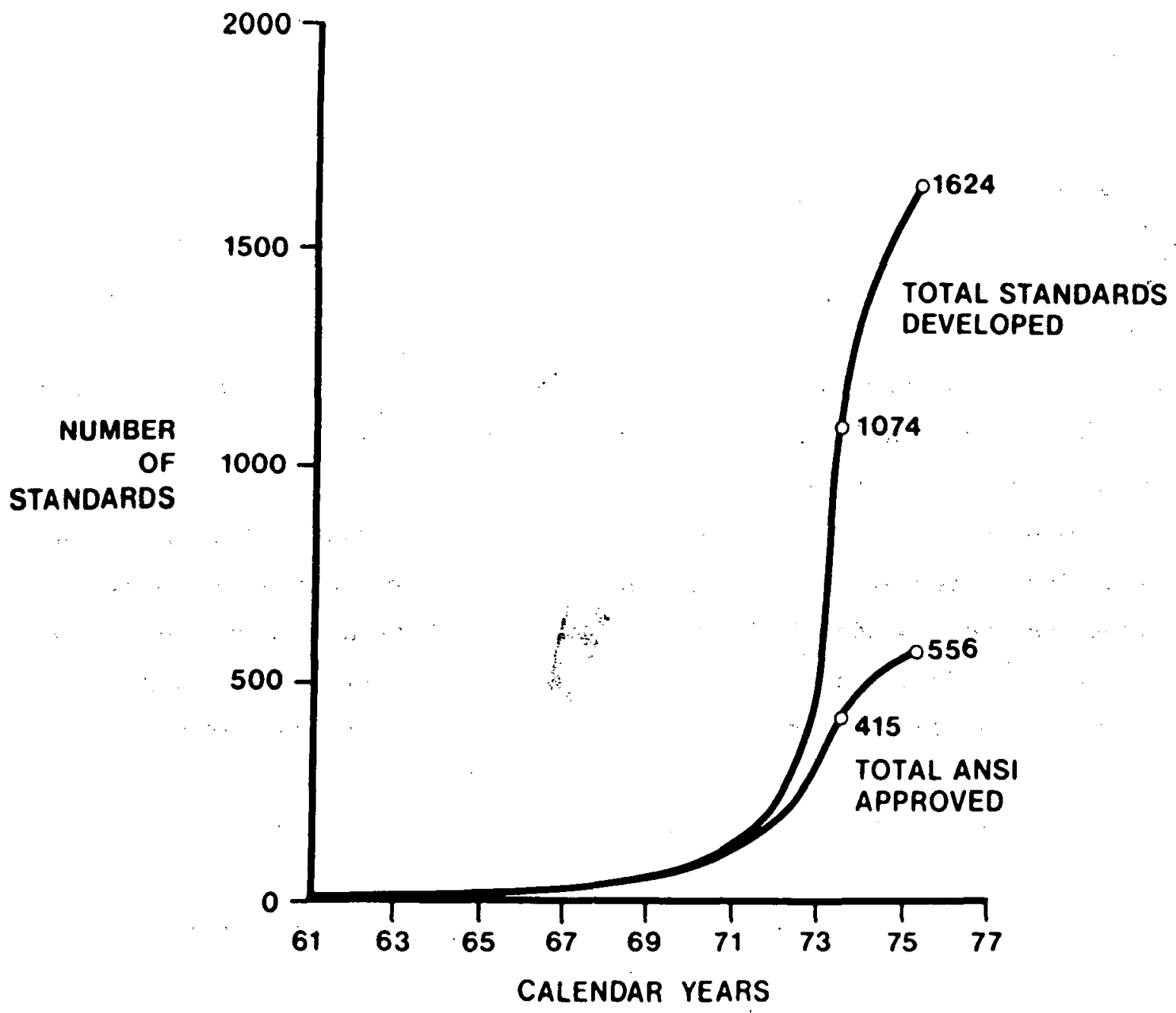

F1g. 3.1. Identifled nuclear application standards cumulative total from 1961 to mid-1975.

the new standards will actually occur over the next few years. Estimates of plant costs will continue to increase as these new standards are applied to plant designs.

The decrease in the growth rate of nuclear standards is encourag1ng, because it implies that existing standards are now perceived to be adequate. However, the Three Mile Island Incident has already initiated serious reevaluation of the need for new standards. ASME, ANS, and IEEE may begin to increase the tempo of standards project approvals. Add1tlonally, the current uncertainty surrounding proliferation, fuel recycle, and waste disposal have not created a climate of utility and public 
confidence. Ultimately, U.S. policies may have a substantial effect on nuclear power plant costs. As a result, projected future plant costs remain uncertain until this policy is resolved.

The number of people in the United States that are working on standards has also grown exponentially. In 1970, about 1450 volunteers were working on nuclear standards for the American National Standards Inst1tute (ANSI). By 1974, 7450 we re Involved in subcommttees and working groups. Data from the serles of historical investment cost studies which UE\&C has done for DOE and 1 ts predecessors show the effect of regulations, codes, and standards on nuclear power plant costs. Figure 3.2 summarizes some of these data.

Regulations in the form of NRC Regulatory Guldes; NRC Branch Technfcal Enviromental Protection Agency requirements, and Occupational Safety and Health Administration requirements have also contributed to higher costs in the same manner as codes and standards. Although some of those requirements existed prior to mid-1974, much of their impact was not felt unt1l the period 1975 and later.

The shaded area in Fig. 3.2 represents the total implied effect on plant cost due to regulations, codes, and standards. The "Estimated Cost" curve given in Fig. 3.2 is based on the total investment costs projected in the historical studies. The "Escalation Only" curve is the projection of an early estImate of costs (reported in WASH-1150), at an escalation rate of eight percent. The "Actual Cost" curve is based on costs for plants which are now operational. The projected dashed portion of the actual cost curve is based on forecasting of utility cost estimates. The shaded area of the graph is the difference between a plant designed In 1969 and a plant of similar design which includes all changes in regulation and schedule that the utility industry has experlenced to date. The data for the escalation of the cost to design, 11cense, and construct nuclear power generating stations are based on the hypothetical "Middletown" site and average labor rates. They do not include owner's costs, discretlonary costs, fees, permits, taxes, or provisions for continued escalation in regulatory requirements.

Early nuclear plants such as Dresden, Quad Cities, Connecticut Yankee, and Browns Ferry were constructed when regulatory requirements were 


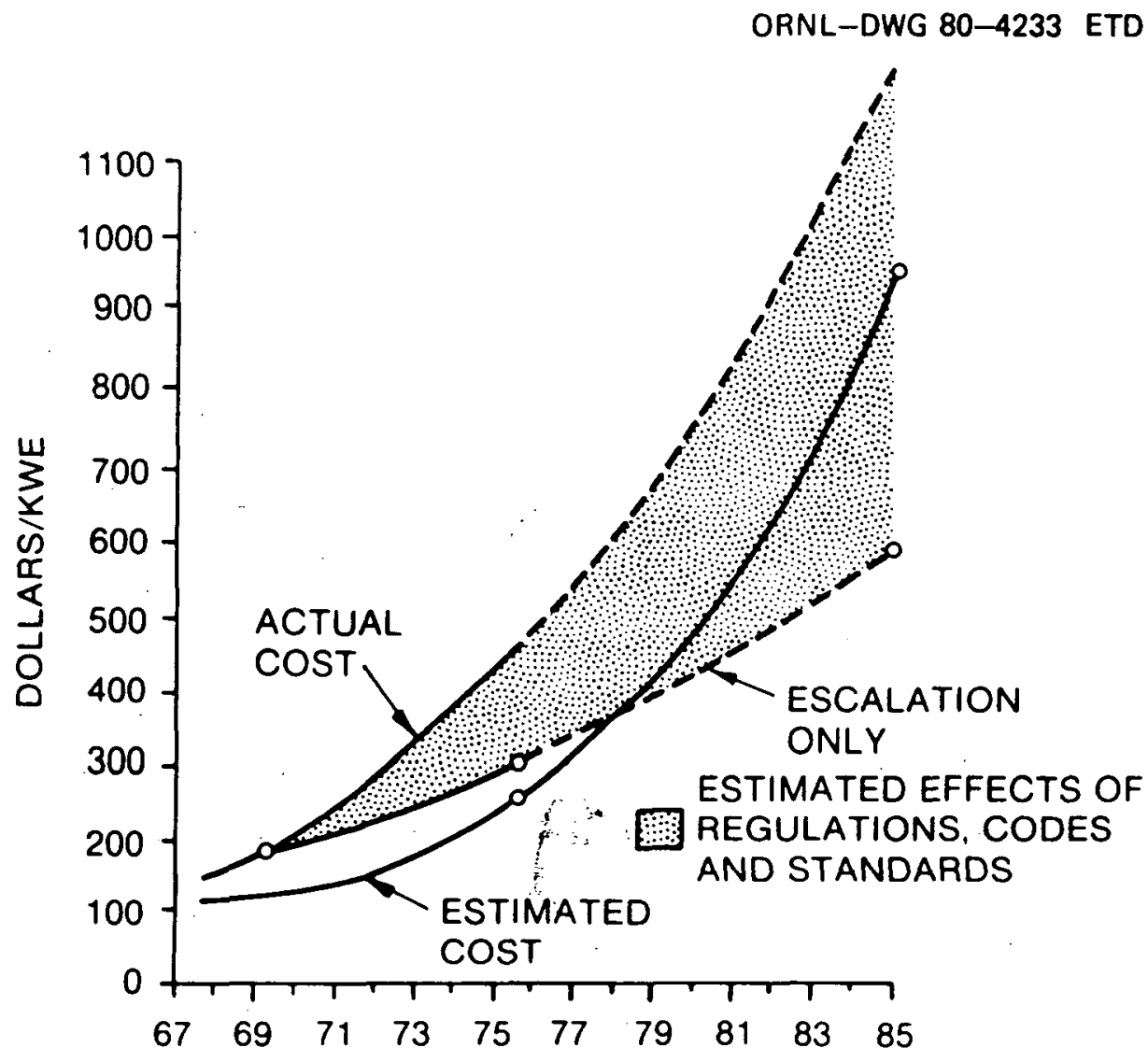

YEAR OF OPERATION

Fig. 3.2. Effect of regulations, codes, and standards on power plant costs.

minimal, and plant labor, materials, and commodities were more consistent with early projections. The design criteria of these plants are comparable to the design criteria for plants represented by the lowe $r$ curve of F1g. 3.2, identifled as "Escalation Only."

\subsection{Impact of Environmental Requirements for Fossil Plants}

Escalating regulatory requirements have developed for fossil plants as well in recent years. Following passage of the U.S. Clean Air Act, many plants burning coal were required to convert to ofl. No sooner had many of these plants converted to ofl when rising o1l imports stimulated new regulations requiring reconversion from oll to coal. 
Other recent regulatory changes for coal plants include water use effects on marine species, particulate emissions, $\mathrm{so}^{2}$ emissions, cooling-tower/stack-gas interactions, off-site nolse levels, $\mathrm{NO}_{x}$ emissions, sludge and waste disposal, ground water effects, trace element: emissions, cumulative climatic effects of world-wide build-up of $\mathrm{CO}_{2}$, and redundant scrubber systems. Standards for a1r-quality and waste management for coal-fired plants are still proliferating. Growth of standards for coal-fired plants will continue for at least several more years before leveling off. Furthermore, implementation of the New Stat1onary Source Performance Standards of 1977 will go into effect during 1979. The lack of implementation experience with these regulations adds further uncertainties to projections for coal-fired plants.

Coal plant costs may thus continue to grow after nuclear plant costs stabilize. It is anticipated that effects similar to those for nuclear power generating stations displayed in Fig. 3.2 are at work on fossil power generating station costs.

\subsection{Miscellaneous Cost Increases}

Construction schedule slippages, caused by effects discussed above, as we 11 as strikes and other delays, cause interest and escalation dur Ing construction costs to rise dramatically. Table 2.1 clearly shows the rise in durations from start-of-project to commercial-operation for both nuclear and fossil power generating stations. Construction sche-dules have increased by approximately 25 percent for nuclear plants and 30 percent for foss 11 plants between mid-197.4 and 1978. The construction period itself has Increased by 20 percent for both nuclear plants and fossil plants between mid-1974 and 1978. As pointed out in the preceding paragraphs, regulatory problems have contributed significantly to these delays. Indications are that this trend is continuing.

Another factor, associated with the impact of construction schedule delays, is the shift of cost sensitivity from the cost of hardware to the cost of recovery. Figure 2.3 clearly shows the rate at which this shift 18 occurring. The proportion of total capital costs of a plant that are time-related costs has increased by almost 40 percent between 
mid-1974 and 1978. On the other hand, base costs have declined to only 45 percent of total capital costs. Therefore, any delay, whether it is related to regulatory, engineering, or construction causes, is of increasing significance in causing costs to rise.

Current design criteria include standards for extensive quality assurance programs. Earlier estimates for plant capital costs in many Instances were based on more conventional standards. Today, quality assurance and quality control programs are far more stringent, which serlously impact the cost of equipment, commodities, and associated design. Furthermore, these additional programs impact field labor manhours and overall construction schedules because of increased procedures and paperwork.

Site-specific costs are sometimes not fully considered in early estimates. Examples might include seismic design, flood protection, extended spent fuel storage, and coollng tower design in lieu of oncethrough cooling. Site-specific items that contribute to the exponential rise in anticipated costs of nuclear plant projects result in doubling and in some cases tripling the commodity estimates. Commodities referred to are the principal commodities of plant construction such as concrete, rebar, structural steel, wire and cable, cable trays, and piping. This was attributed to better definition of plant design and evolving safety and environmental criteria. Craft labor manhours have increased proportionately. If labor strikes are not considered,-current estimates for craft labor are over two times the original estimated manhours. It is reasonable to expect the labor content to double when the quantity of commodities has doubled.

Strikes and other delays have occurred in certain projects that have resulted in hundreds of work stoppages causing schedule extensions extending into years of delay. Interest during construction not only. increases with time but is also compounded by expanding escalation.

\subsection{Future Cost Uncertainties}

While there are indications that the rate of cost increases for nuclear power plants is tending to level off, the impact of the Three Mile 
Island incident may cause a reversal of the current trend. Expectations for fossil power plant costs are not optimistic. Implementation of the Fuel Use Act will have additional impacts on costs that were rising rap1dly beforehand. Even though interpretation of the Act and rules for exemptions are still being resolved, it is apparent that it may be years before the total comparative economics of conversion of oil to coal, new coal plants, and nuclear plants are fully determined. Escalation and Interest rates are expected to continue to rise. Construction schedules are not expected to improve significantly in the near future.

Cost studies by UE\&C to support the Energy Economic Data Base will continue in 1979 and 1980. The factors discussed herein will continue to be evaluated as well as the effects of future design changes. 
4. THE CONCEPT CODE

The planner needs a method for obtaining plant investment cost estimates that are in conformance with the particular plant size, location, timing, and economic conditions applicable to the proposed project. Further, these estimates should be easily obtainable and should provide adequate detall about the individual components of the total plant cost in a standardized accounting format that identifies both direct and indirect costs.

These objectives are satisfied by the CONCEPT computer program that has been developed within the Plans and Analysis Division of the Office of Nuclear Energy Programs. Work carried out at ORNL has produced several successive versions of this capital investment cost estimation program called CONCEPT. 19-24

The code is designed primarily for use in examining average trends in plant costs, evaluating important elements in the cost structure, determining sensitivity to technical and economic factors, and providing reasonable projections of costs. Although the code is not intended to be used as a substitute for detalled engineering cost estimates for specific projects, it has been organized to facilitate modifications to the reference plant cost models so that estimates may be taflored to a particular project. The computer code provides a consistent and rapid means of estimating power plant capital investment costs with various assumed sets of economic and technical ground rules. The code is also used to perform sensitivity studies, as fllustrated in this report.

The computer code is described in detail in other reports; 19-24 however, a summary description is presented here for completeness. The CONCEPT code is designed to provide detalled cost estimates, including costs for all subaccounts down through the five-digit account level. In addition, each subaccount is broken down into costs for factory equipment, site materials, and site labor. This code uses the account numberIng system described in Refs. 3 and 9-12.

The procedures used in the CONCEPT code 24 are based on the premise that any central station power plant involves approximately the same 
major cost components, regardless of location or date of initial operation. Therefore, if the trends of these major cost components can be established as a function of plant type and size, basic labor and materials costs, and interest and escalation rates, a cost estimate for a reference case can be adjusted to fit any case of interest. The application of this approach requires a detalled "cost model" for each plant type at a reference condition and the determination of the cost-trend relationships.

The present CONCEPT code contains cost models for single unitg and first and second units of PWR and BWR nuslear stations and single units and first, second, and third units of high-sulfur and low-sulfur coalfired stations. Reference 24 contains a listing of a typical cost model, based on Refs. 9-13. The cost models presently contalned in CONCEPT have been revised in accordance with the EEDB.revisions described in Section 2.8. The present version is based on safety and environmental licensing criteria and cost data in effect as of January 1978.

The reference plants are assumed to be located at the hypothetical Middletown site, which is described in considerable detall in Refs. 3 and 9-12. This site is reasonably favorable, in most respects, including an adequate supply of cooling water, low population density, satisfactory transportation facilities, and sufficient labor supply.

The major account direct and indirect costs for the reference plants are described as a function of size by classical exponential scallng relationships, which are belleved to be representative of capital investment cost trends for unit sizes in the range of 500 to 1500 MWe, but which may also be used outside this range with greater uncertainty.

The cost model for each type of plant includes distributions or "mixes" of labor and materials by various classifications, which are used in calculating weighted average cost indexes for adjusting base costs to other locations and for escalating costs into the future.

The calculation of escalation during construction and interest durIng construction requires cash flow curves for each major account, and a set of cash flow curves is provided with each model data set. Typical curves for nuclear and fossil plants are illustrated in F1gs. 4.1 and 4.2 . 
ORNL-DWG 78-18492

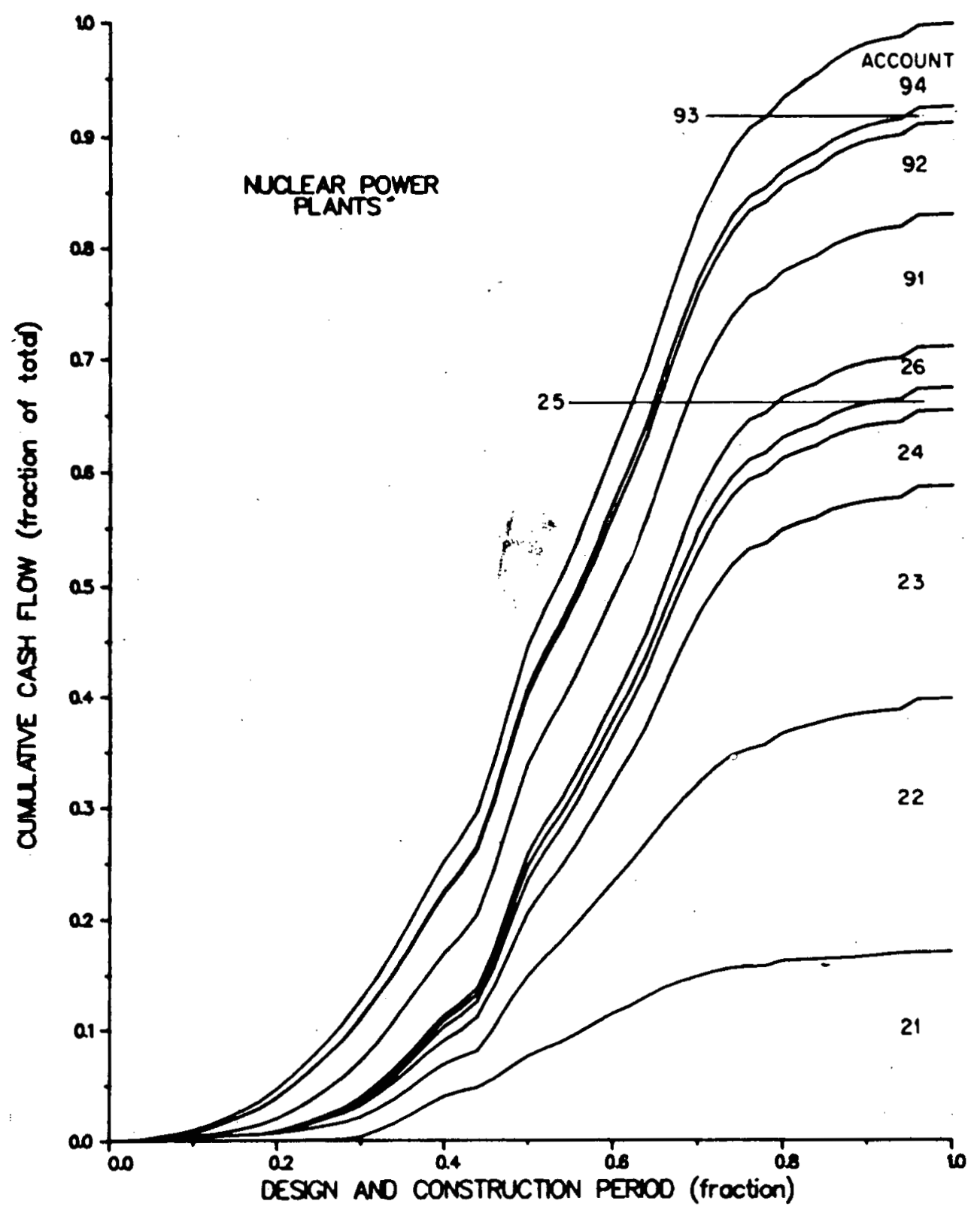

F1g. 4.1. Typical cumulative cash flow curves for major cost accounts - nuclear power plants. 


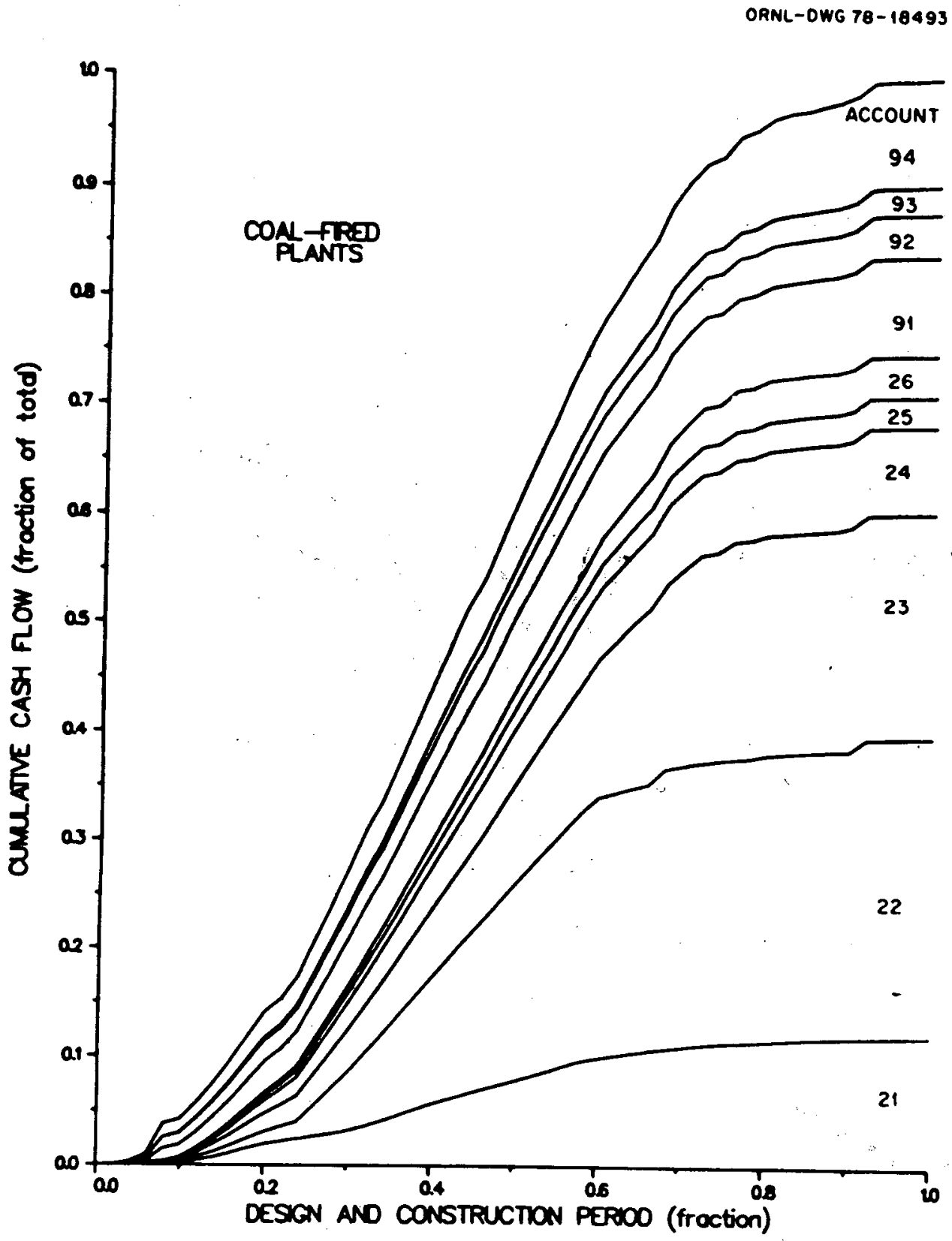

Fig. 4.2. Typical cumulative cash flow curves for major cost accounts coal-fired power plants. 
To generate a cost estimate under spectfic conditions, the CONCEPT user specifies the plant type and location, net electrical capacity, date of purchase of steam supply system, data of construction permit, date of commercial operation, and interest rate. If the specified plant size is different from that of the reference plant, the costs for each major account are adjusted by using scaling functions that define the cost as a function of plant size. This initial step gives an estimate of the costs for a plant of the spectfied type and size at the reference date and location.

The code has access to cost-index data files for 20 major cities in the United States, two in Canada, and the hypothetical Middletown site (see Fig. 4.3). These files contain data on equipment cost indexes, materials costs, and construction craft wage rates as reported by U.S. government and trade publications $25-29$ over the past 15 years. These data are used to determine historical trends in escalation of equipment, labor, and materials costs. If desired, the escalation trends can be based on only a selected portion of the available historical data and projected Into the future as an exponential function of time.

These cost-1ndex data are then used in CONCEPT to modify the cost accounts from the reference location to the selected location and to adjust costs to different dates (elther earlier or later than the cost model reference date). Each cost account is adjusted and escalated separately, using the labor, material, and equipment mixes appropriate to that account.

As an example of the procedures outlined above, assume that a reference cost model is avaflable for an 1100-MW(e) PWR located at the hypothetical Middletown site, based on construction beginning in early 1978 and that a cost estimate is needed for a 1200-MW(e) PWR located near Ch1cago with construction beginning in early 1980 and reaching commercial operation in mid-1986. The code produces the new estimate by scaling costs to the 1200-MW(e) size, adjusting each cost account by the ratio of projected 1980 costs at Chicago to 1978 costs at Middletown, and then estimating escalation during construction and interest during construction. The procedure is 1llustrated schematically in Fig. 4.4. 


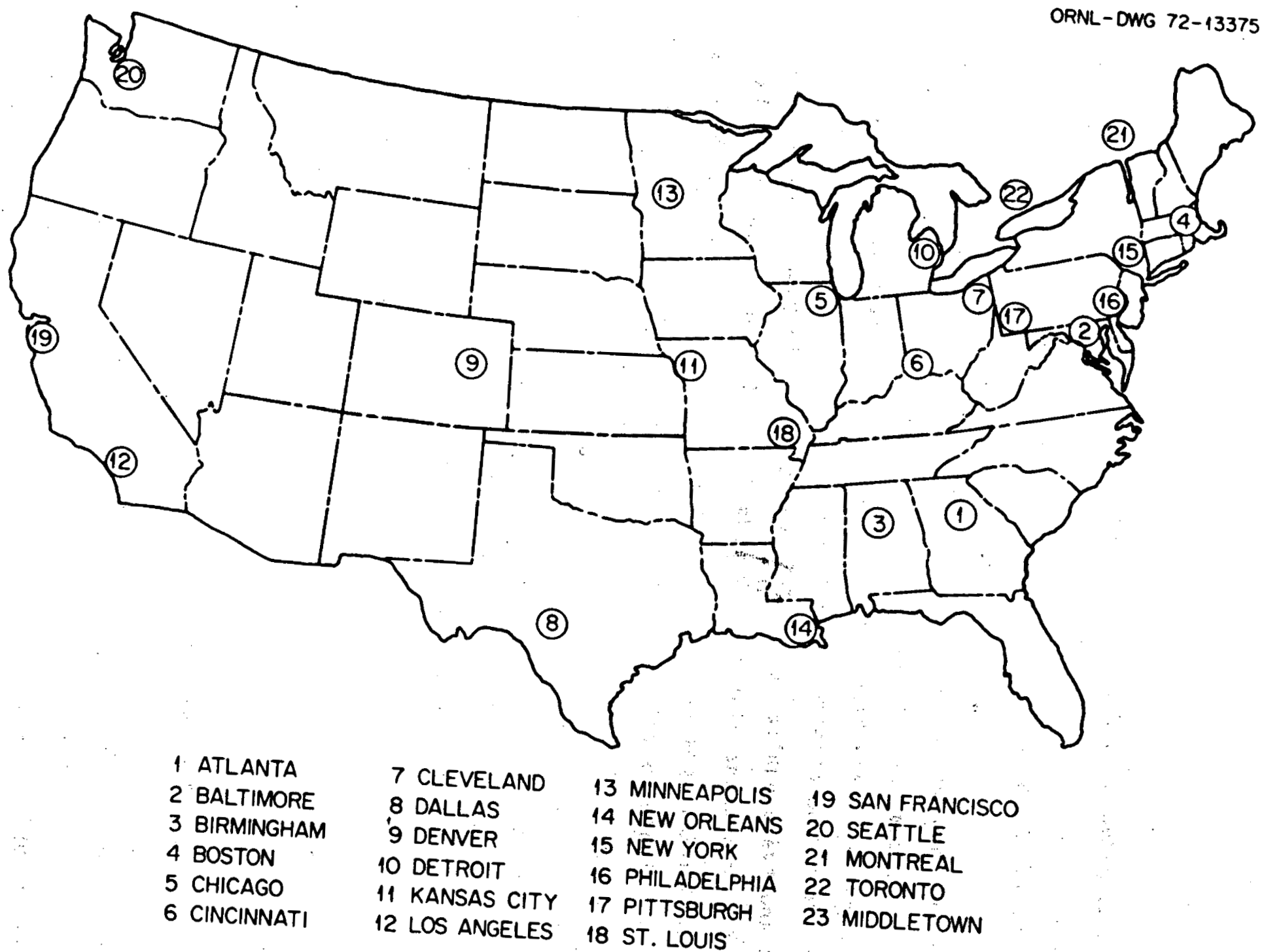

cost Index data are stored in CONCEPT. 
ORNL - DWG 75.4433A
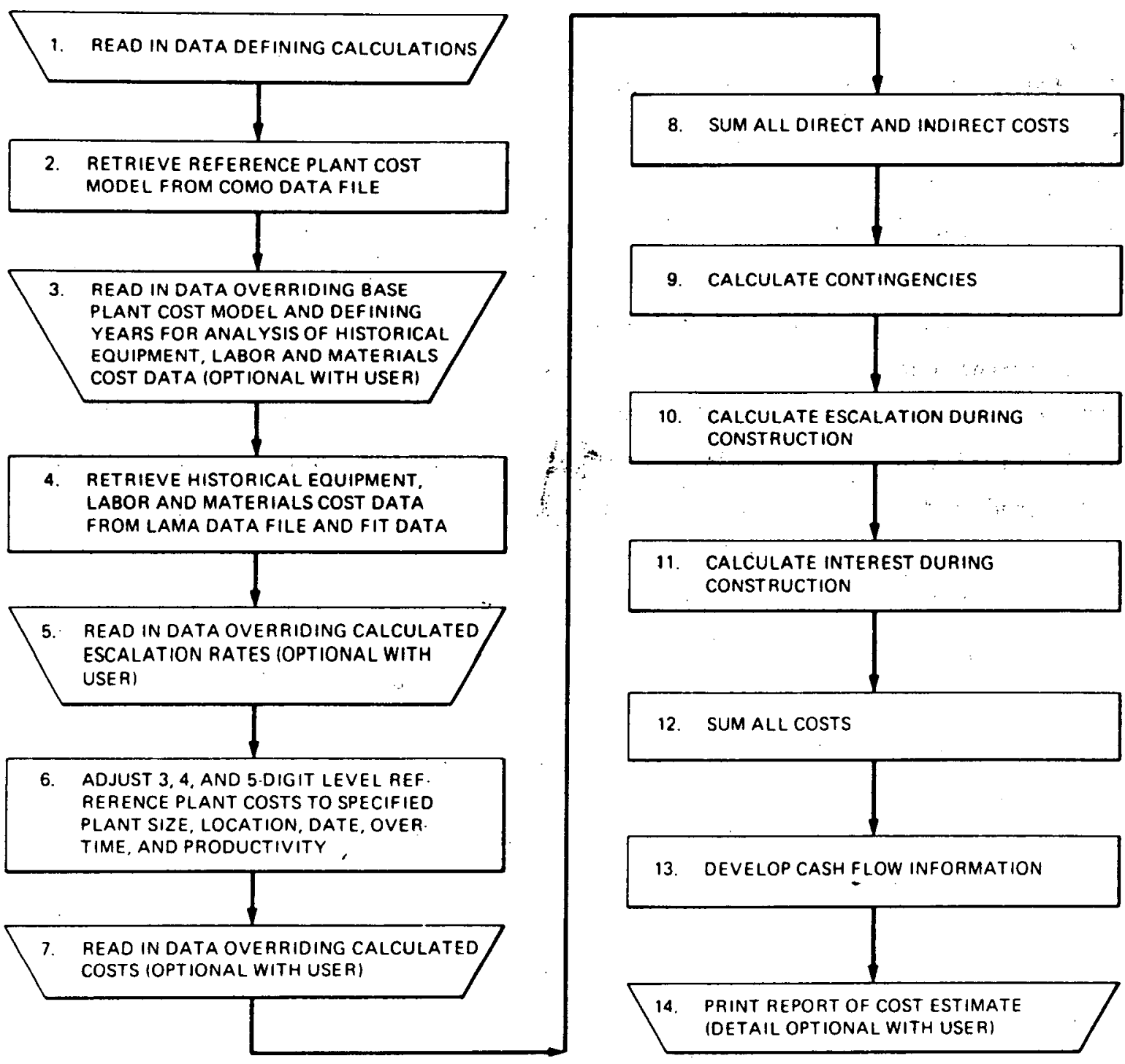

Fig. 4.4. General flow of calculations in CONCEPT-5. 


\section{' 5. PLANT CAPITAL INVESTMENT COST ESTIMATES USING CONCEPT}

The CONCEPT code was used to develop capital investment cost est1mates for power plants entering service in early 1990. Ground rules for the base cases are summarized in Table 5.1. The costs of the main stepup transformer and electric power transmission facilities at the power plant site are not included in the estimates. The plant location is assumed to be the hypothetical Middletown site. Cost index data for Middletown represent a composite of Boston, New York, and Philadelphia data In equal proportions, and the historical data and fitted curves are lllustrated graphically in Figs. 5.1 and 5.2 for craft labor, in Figs. 5.3 and 5.4 for site-related materials, and in Figs. 5.5 and 5.6 for equipment. CONCEPT models used in this study we re the 1139-MW(e) PWR model, the 795MW(e) coal-fired model with tandem-compound turbine, and the 1232-MW(e) coal-fired model with cross-compound turbine. Both coal models include

flue gas desulfurization equipment.

The CONCEPT estimates for both interest during construction and escalation during construction are based on the cumulative cash flow curves shown previously in Figs. 4.1 and 4.2. The term "interest during construction" as used here is the same as "allowance for funds used during construction" (AFUDC). AFUDC is a charge made against the cost of a plant to compensate debt and equity investors in the utility for the use of their money during the long period between the time funds for building the unit are spent and the time the unit goes into operation. Escalation during construction accounts for inflationary increases in costs from the time the estimate is made to the time that actual costs are incurred. The total cumulative cash flow curves for the base cases defined in Table 5.1 including escalation during construction and interest during construction are shown in Fig. 5.7.

For thè common date of commercial operation January 1990, Fig. 5.7 11lustrates that the date the steam supply system is ordered for fos811 plants is four years later (1984 Instead of 1980) than for nuclear plants. Thus, the start of design and construction costs for the fossil plants are escalated to this later date, 1984. On the other hand, interest and escalation costs during construction for fossil plants will be 
ORNL-DWG 80-4234 ETD

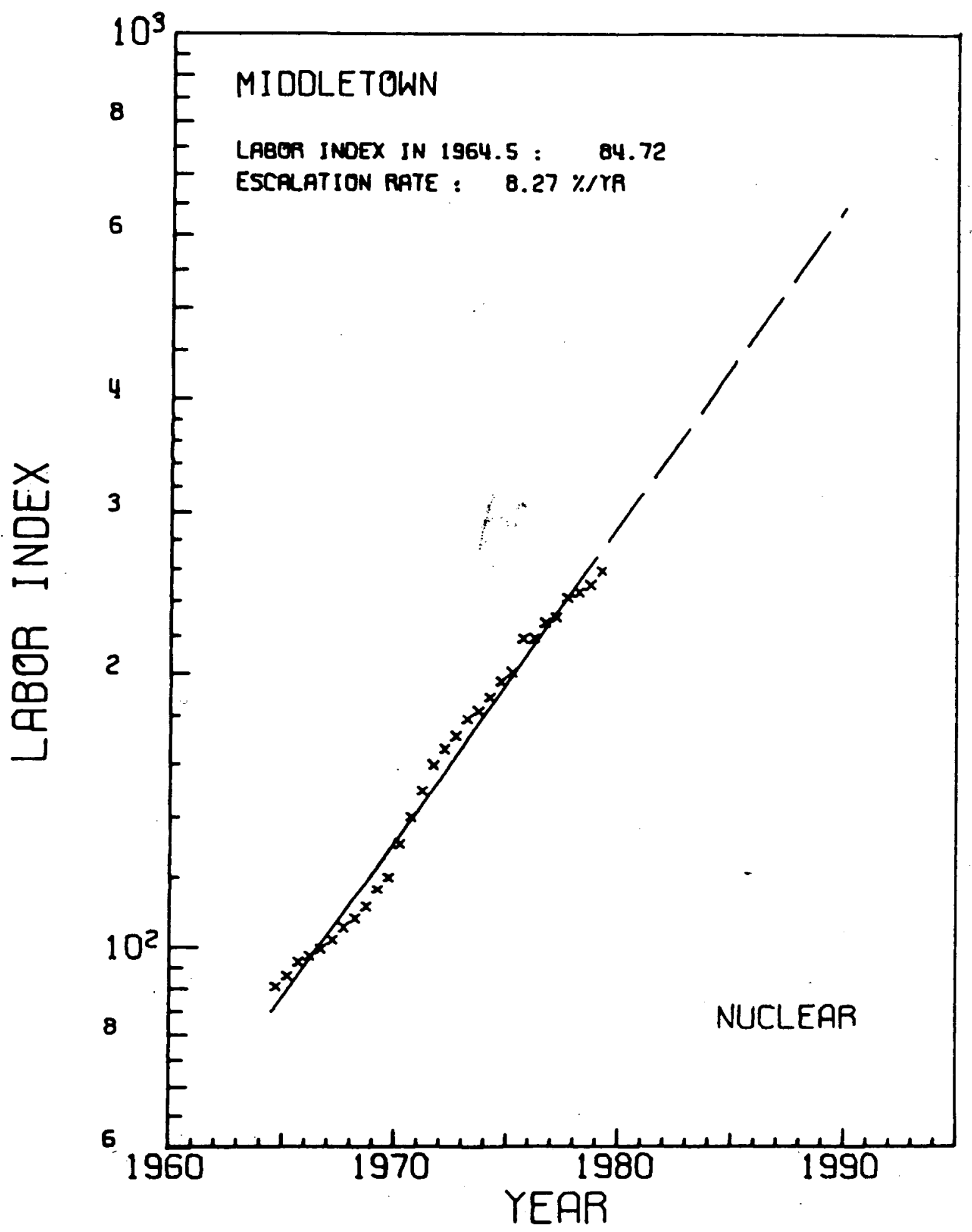

F1g. 5.1. Craft labor cost Index data for LWR power plants. 
ORNL-DWG 80-4235 ETD

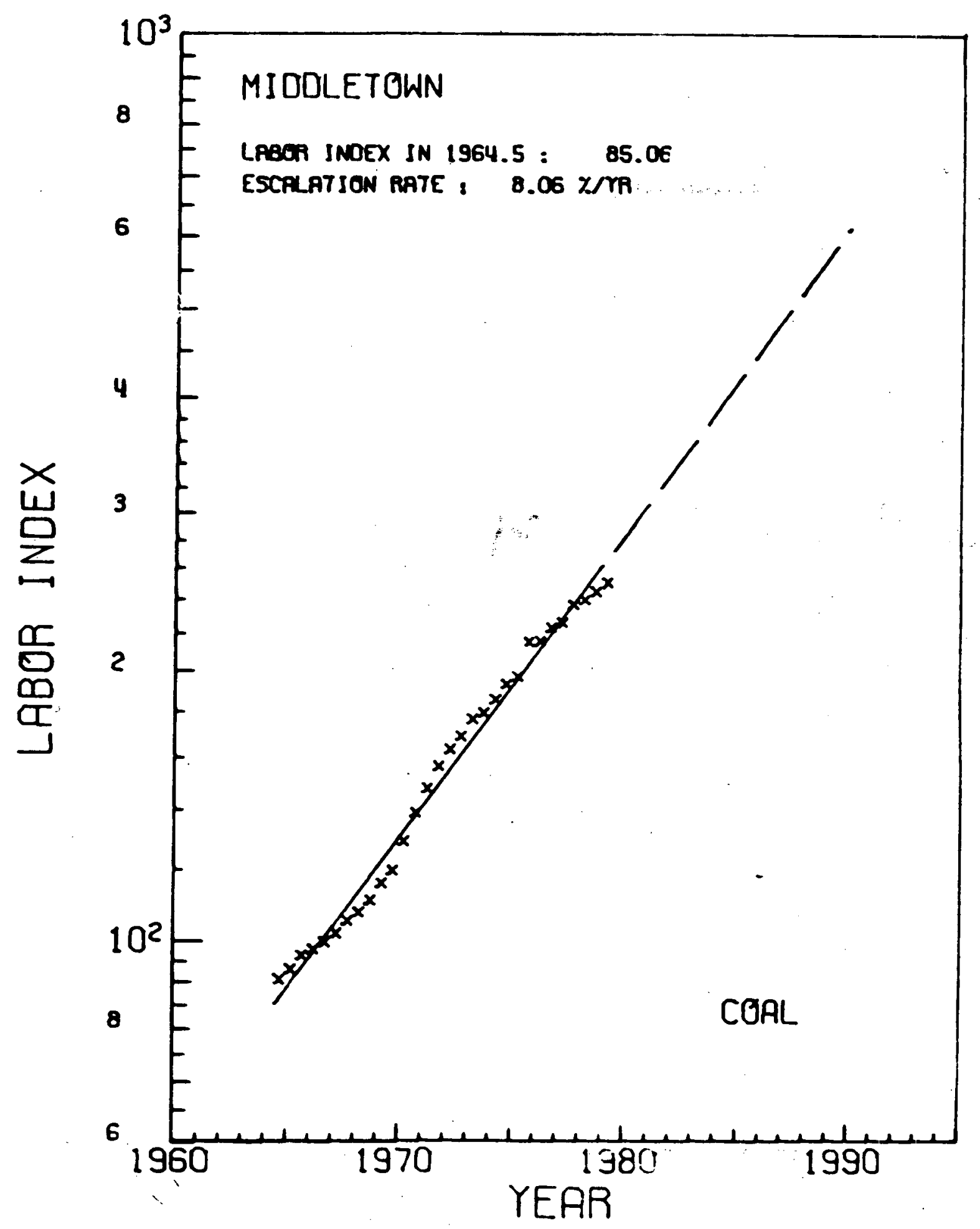

F1g. 5.2. Craft labor cost Index data for coal-fired power plants. 


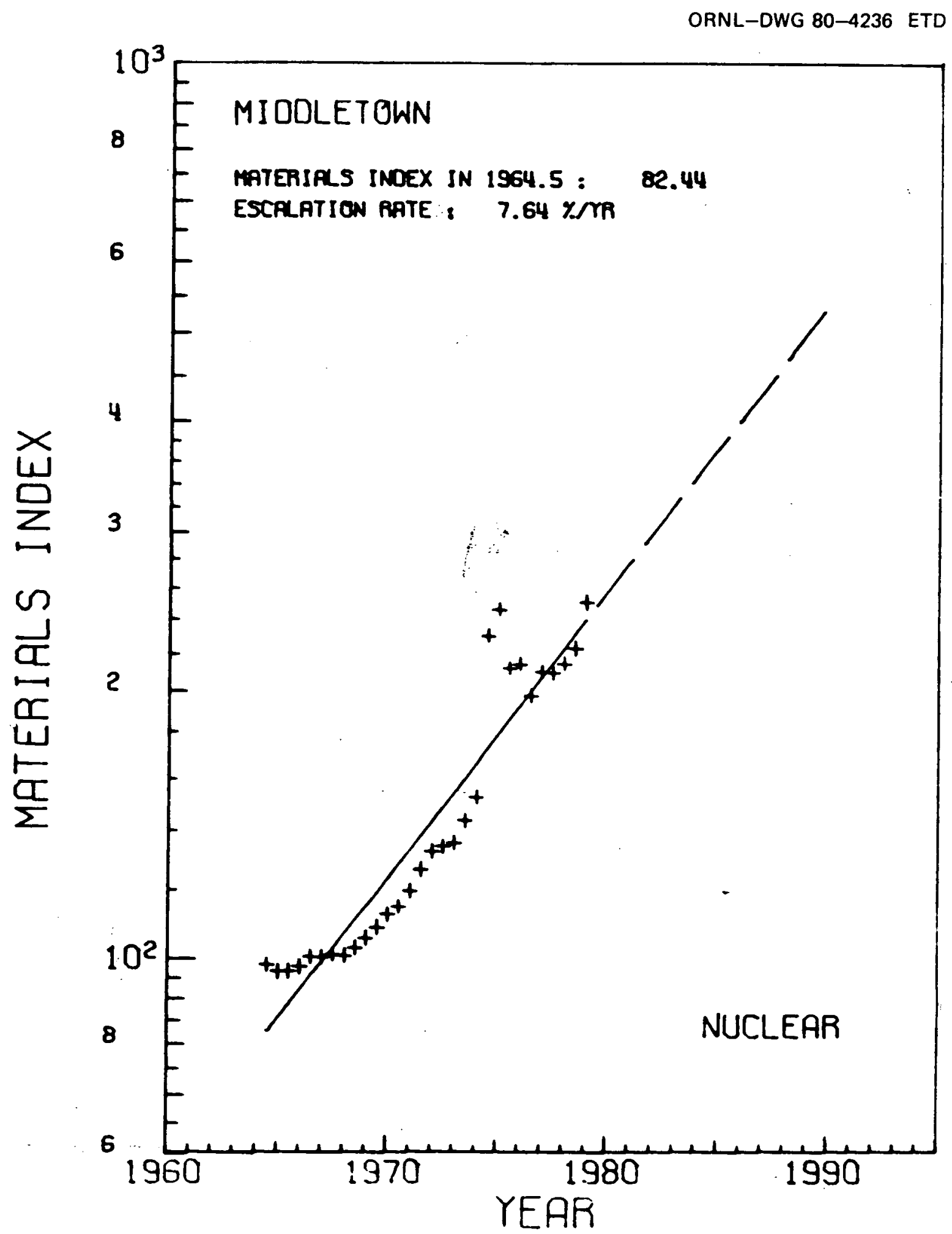

Fig. 5.3. Site-related materials cost Index data for LWR power plants. 
ORNL-OWG 80-4237' ETD

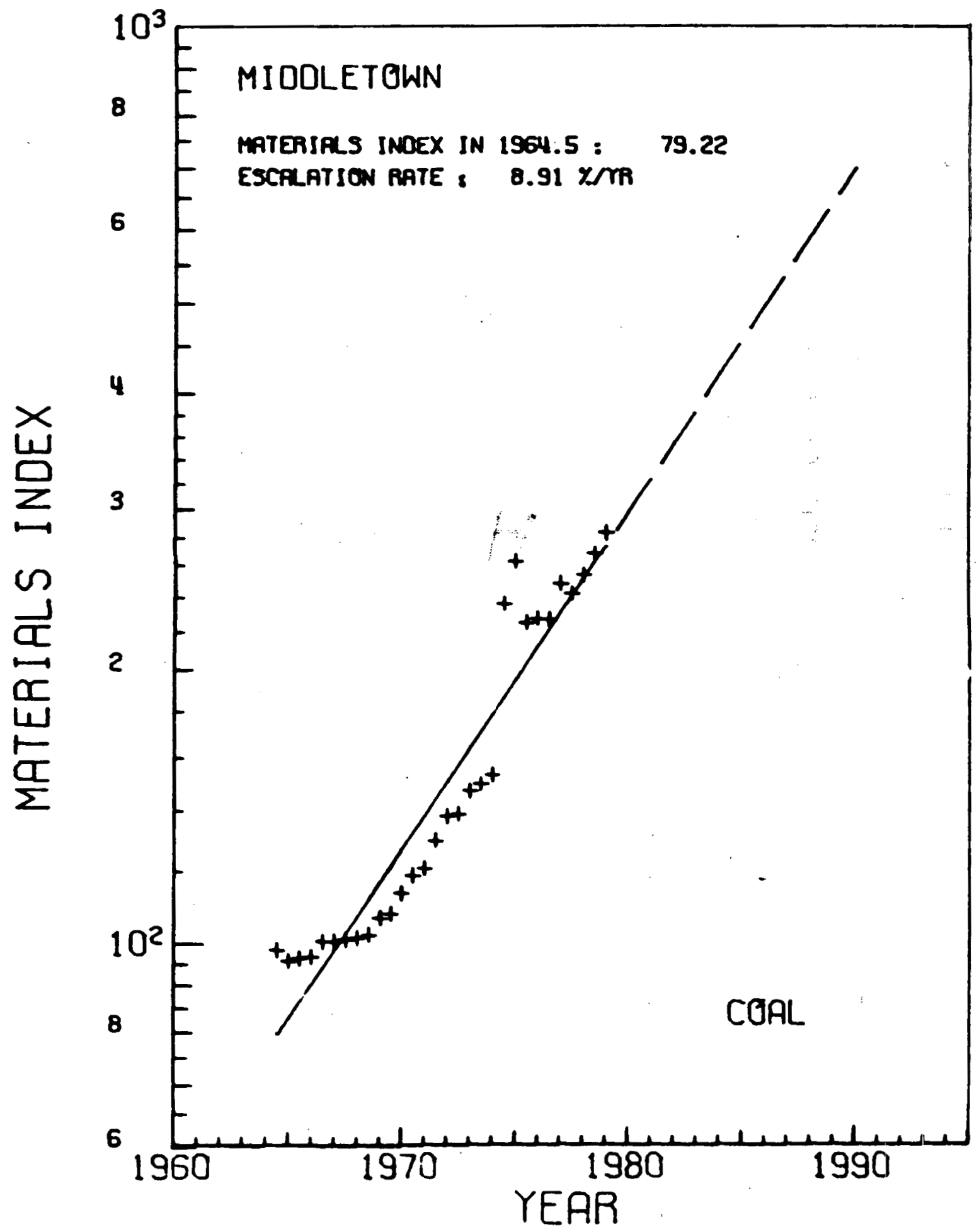

F18. 5.4. S1te-related materlals cost index data for coal-fired power plants. 


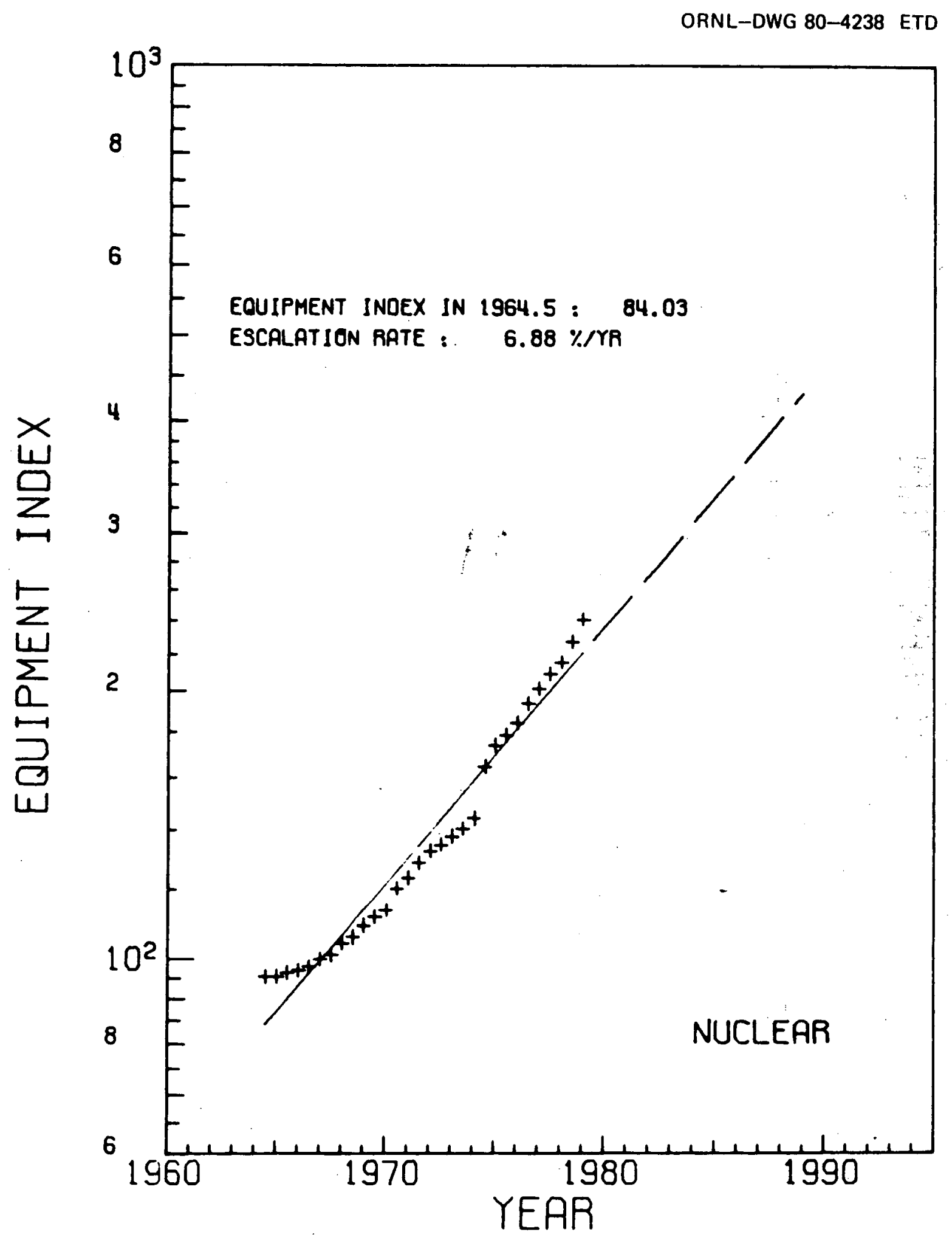

F1g. 5.5. Equipment cost Index data for LWR power plants. 
ORNL-DWG 80-42:39 ETD

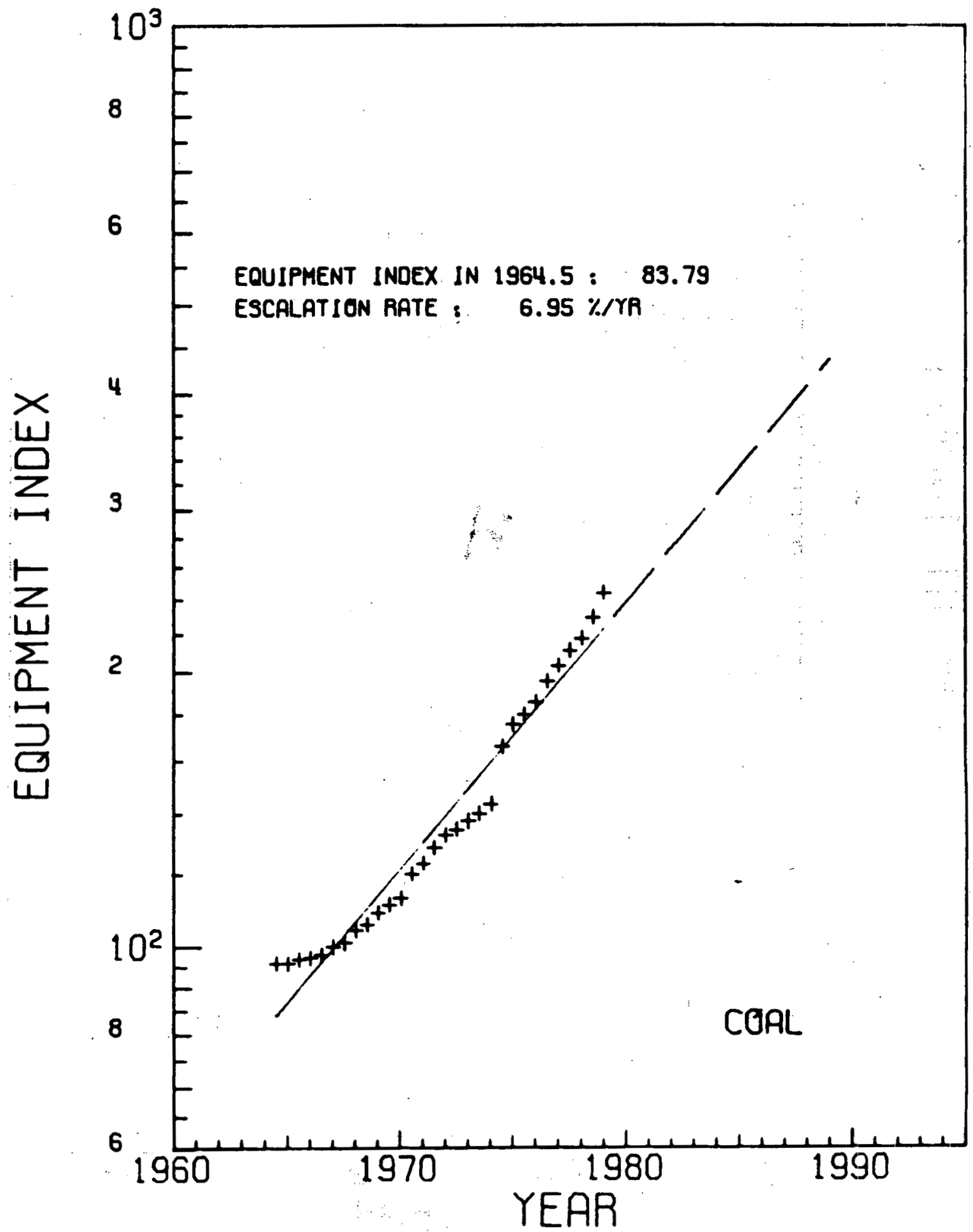

F1g. 5.6. Equipment cost index data for coal-fired power plants. 


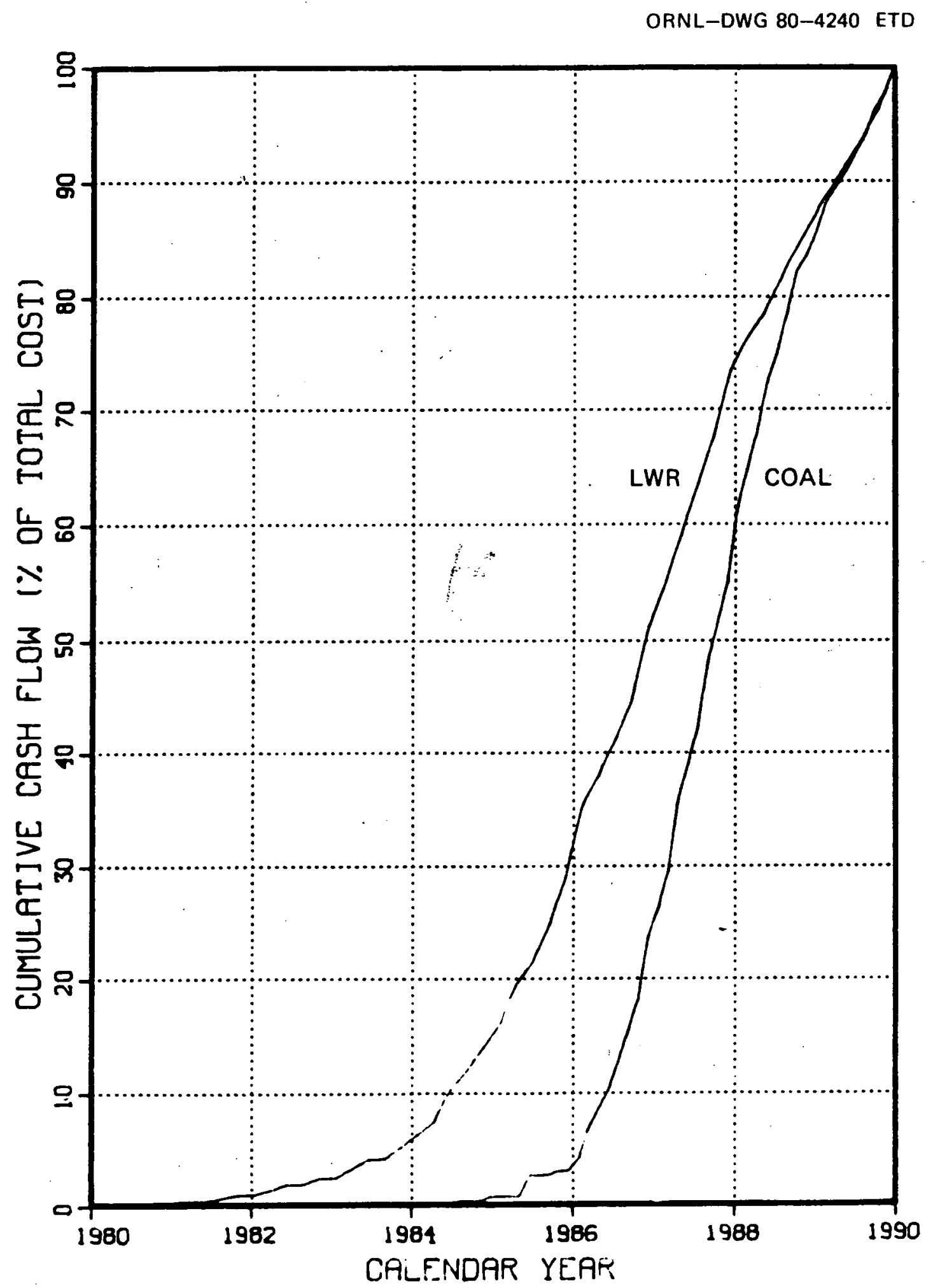

F1g. 5.7. Distribution of cash flow for base capital Investment cost estimates including escalation and interest during construction. 
Table 5.1 Ground rules for plant capital Investment cost estimates

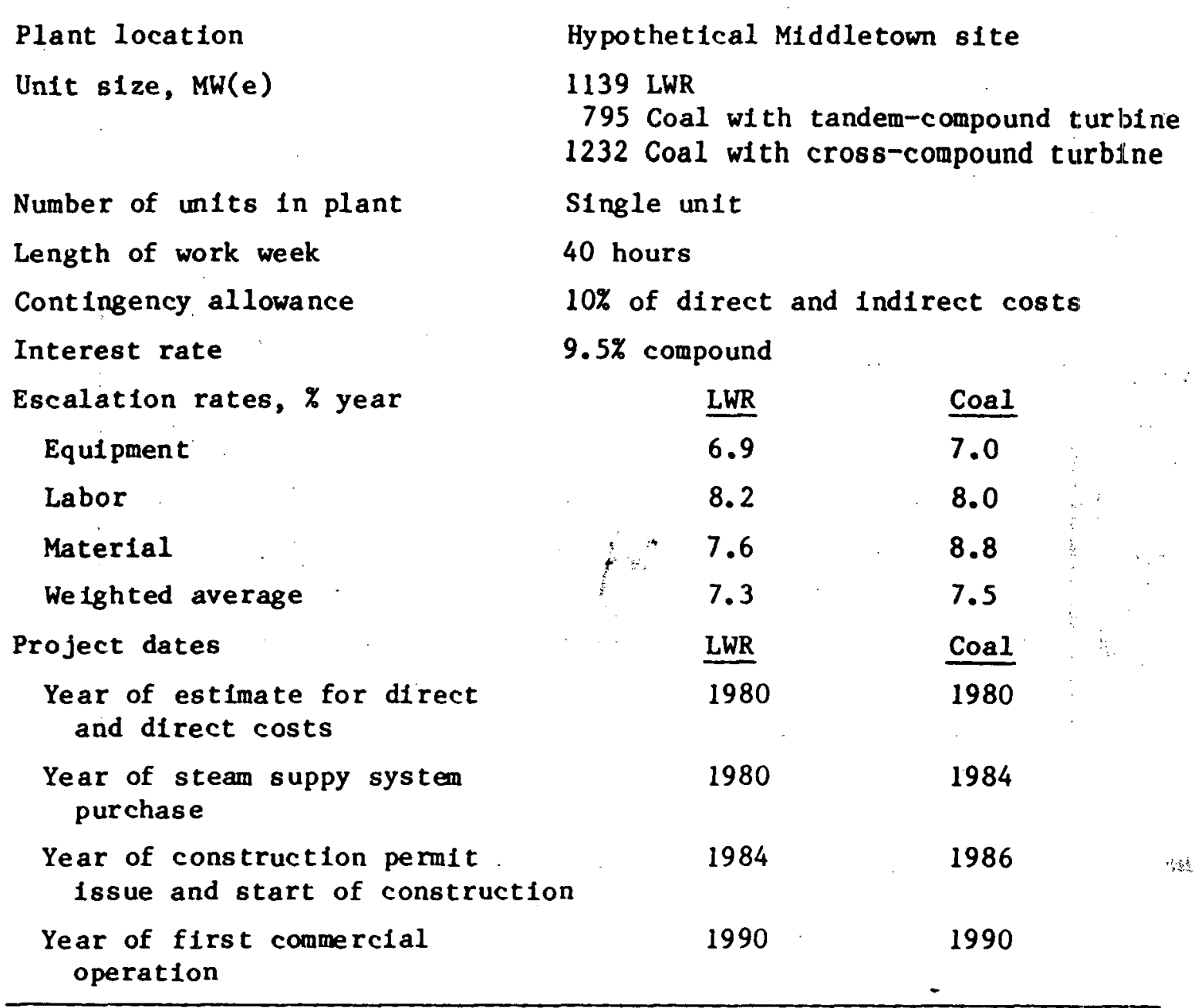

lower than those for nuclear plants because of the shorter design and construction period.

The resulting plant cost estimates for LWR and coal-fired plants are given in Table 5.2. The direct costs are presented in seven major accounts:... land and land rights, structures and improvements,.. reactor/ boiler plant equipment, turbine plant equipment, electric plant equipment, miscellaneous plant equipment, and maln heat rejection systen. The accounting system used in CONCEPT is patterned after the Federal Power Commission (FPC) Uniform System of Accounts but differs in several $81 \mathrm{~g}$ nificant respects. 'In CONCEPT the main steam piping, extraction stean 
Table 5.2 Capital investment cost estimates for base plants for commerclal operation In January 1990

\begin{tabular}{|c|c|c|c|}
\hline & $\begin{array}{c}1139-\mathrm{MW}(e) \\
\operatorname{LWR}\end{array}$ & $\begin{array}{c}\text { 795-MW(e) } \\
\text { Coal }\end{array}$ & $\begin{array}{c}1232-\mathrm{MW}(e) \\
\operatorname{Coal}\end{array}$ \\
\hline \multicolumn{4}{|l|}{ Direct costs (millions of dollars)a } \\
\hline Land and land rights & 2 & 2 & 2 \\
\hline Stuctures and improvements & 136 & 55 & 68 \\
\hline Reactor/boiler plant equipment & 172 & 155 & 215 \\
\hline Turbine plant equipment & 144 & 82 & 150 \\
\hline Electric plant equipment & 50 & 37 & 43 \\
\hline Miscellaneous plant equipment & 17 & 11 & 13 \\
\hline Ma1n heat rejection system & 25 & 14 & 18 \\
\hline Subtotal (direct $\cos t 8)$ & 546 & 356 & 509 \\
\hline \multicolumn{4}{|l|}{ Indirect costs (millions of dollars)a: } \\
\hline Construction services & 87 & 46 & 65 \\
\hline Home of fice engineering and services & 104 & 18 & 21 \\
\hline Fleld office engineering and services & 34 & 13 & 18 \\
\hline Owner's costs & 53 & 38 & 45 \\
\hline Subtotal (1ndirect costs) & $\underline{278}$ & $\underline{115}$ & $\underline{149}$ \\
\hline Direct and indirect costs & 824 & 471 & 658 \\
\hline Contingency allowance & 82 & 47 & 66 \\
\hline \multicolumn{4}{|l|}{ Total costs (millions of dollars) } \\
\hline Total direct and indirect $\cos \mathrm{ts}^{a}$ & 906 & 518 & 724 \\
\hline $\begin{array}{l}\text { Allowance for escalation to NSSS/ } \\
\text { boller purchase date }\end{array}$ & 0 & $\underline{174}$ & $\underline{243}$ \\
\hline $\begin{array}{l}\text { Total direct and indirect costs at } \\
\text { NSSS/boller purchase date }\end{array}$ & $906^{a}$ & $692^{b}$ & $967 b$ \\
\hline $\begin{array}{l}\text { Allowance for escalation during } \\
\text { construction }\end{array}$ & 477 & 178 & 251 \\
\hline $\begin{array}{l}\text { Al lowance for interest during } \\
\text { construction }\end{array}$ & $\underline{608}$ & $\underline{256}$ & $\underline{354}$ \\
\hline \multicolumn{4}{|l|}{$\begin{array}{l}\text { Plant capital 1nvestment cost estimate } \\
\text { at commercial operation }\end{array}$} \\
\hline Millions of dollars & 1991 & 1126 & 1572 \\
\hline Dollars per kllowatt & 1748 & 1416 & 1276 \\
\hline
\end{tabular}


piping, feedwater and condensate piping, feedwater heaters, and feedwater pumps are included in the turbine plant equiment account. The FPC system of accounts includes the above in boller or reactor plant equipment accounts. In addition, indirect costs, "contingency allowance, escalation during construction, and interest during construction are included in FPC electric plant accounts as opposed to the separate treatment in CONCEPT. Indirect custs and a contingency allowance are added to the direct cost subtotal to arrive at a cost estimate expressed in dollars current to the estimate date. Steam supply order date costs for coal-fired plants include escalation to January 1984 while those for LWR plants Include escalation only to January 1980. The addition of escalation and interest during the design and construction period yields the estimated total investment cost at commercial operation in January 1990. 


\section{COST SENSITIVITY STUDIES}

In this part of the study, capltal investment costs for LWR and coal-fired plants were estimated as functions of individual parameters, such as unit size, site labor productivity, site labor overtime, lead. time for design and construction, escalation (or inflation) rates, date of infitial commercial operation, interest rate for funds used during construction, and plant location. As each parameter was varied, all other parameters were held constant as specified in the ground rules of Table 5.1. In this manner the sensitivity of total estimated plant capital investment costs to each parameter was developed.

\subsection{Unit Size}

Capital investment costs were estimated for unit sizes from 600 through $1300 \mathrm{MW}(\mathrm{e})$. The unit capital investment costs presented in Fig. 6.1 Illustrate the importance of the cost scaling effect w1th increasing' unit size. The discontinuity in the coal curve is due to the shift from tandem-compound to cross-compound turbines in the 900-1000 MW(e) range. As 1llustrated in Fig. 6.1, LWR plants are more competitive in the larger size range. In the $1300-\mathrm{MW}(\mathrm{e})$ size, an LWR plant would cost almost $\$ 400 /$ $\mathrm{kW}(\mathrm{e})$ more than a coal-fired plant, whlle in the 600-MW(e) size, an LWR plant would cost about $\$ 800 / \mathrm{kW}(e)$ more than a coal-fired plant:

\subsection{Construction Labor}

Based on data avallable in early 1978, it was estimated that construction of a single-untt 1139-MW(e) LWR plant would require about 9.8 manhours of construction labor per kilowatt of electrical capacity. Construction of a single-unit 795-MW(e) coal-fired plant would require about 8.2 manhours/kW(e) and a 1232-MW(e) coal-fired plant about 7.3 manhours/ $\mathrm{kW}(\mathrm{e})$.

The effective productivity of construction labor varies significantly even within a local area depending on factors such as the general 
ORNL-DWG 80-4241 ETD

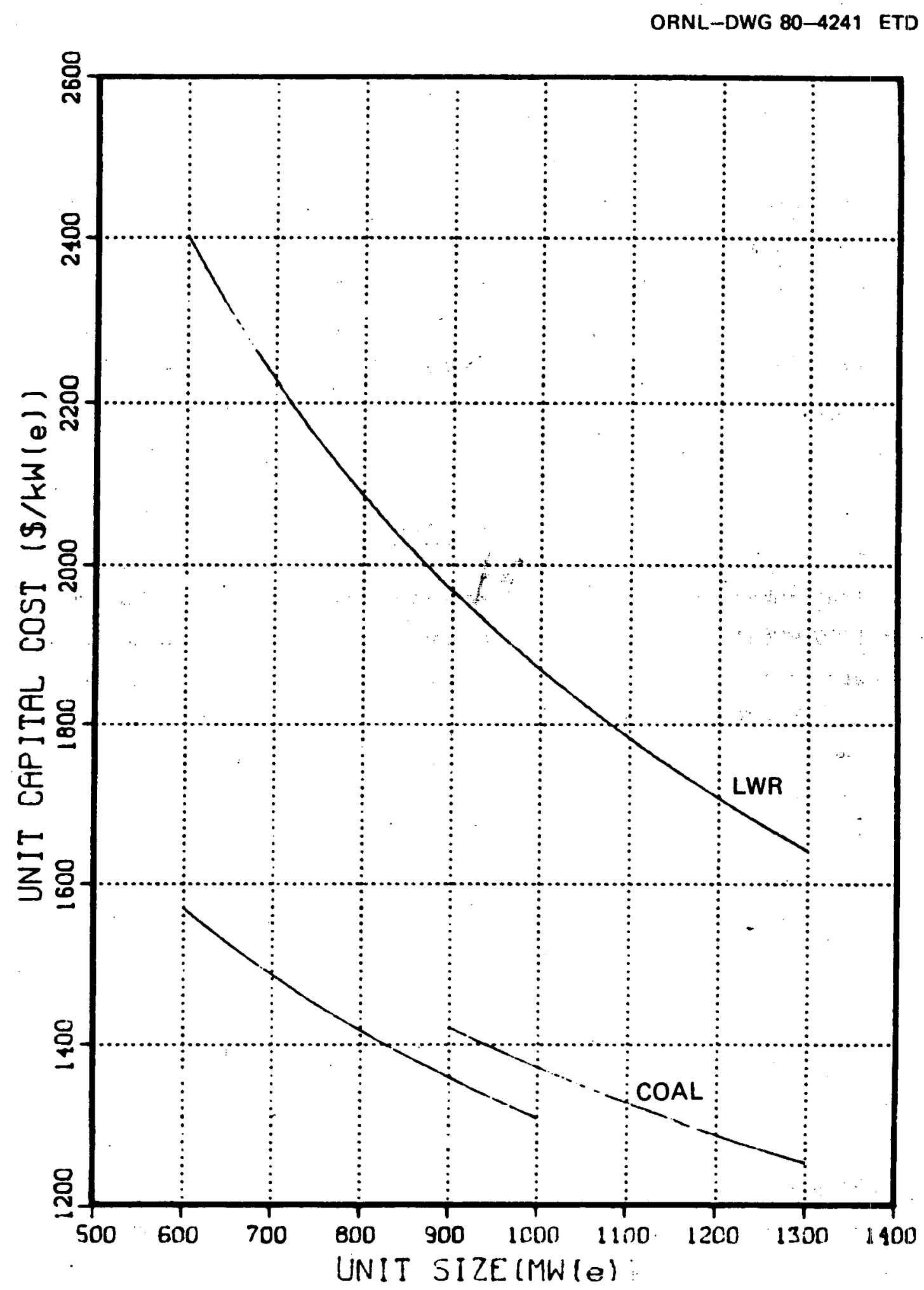

F1g. 6.1. Estimated power plant capital investment costs as a function of unit size for 1990 operation. 
economy, project management, labor relations, job conditions, availability of equipment and materials, and weather. The construction labor requirement was treated as a parameter ranging from 6 to 15 manhours/ $\mathrm{kW}(\mathrm{e})$, assuming a 40-hour work week with no overtime pay. Figure 6.2 shows estimated plant costs for LWR and coal-fired plants as a function of construction labor requirements. Total plant costs increase about 2-3\% for each additional manhour per kilowatt of electrical capacity.

\subsection{Overtime Work}

In some labor markets it is necessary to guarantee some overtime work to secure the necessary work force. However, routine overtime schedules tend to decrease worker effectiveness and productivity. Experience indicates that overtime work, is most effective when sustained for short periods and at relatively few hours beyond the nominal 40-hour workweek.

Figure 6.3 shows typical data, based partly on Refs. 30-32, for the estimated relative efficiency and net effective productive hours for rout1ne overtime schedules when sustalned over many weeks. As shown in the lower curve, experience indicates decreased efficlency with sustained overtime. The upper curve shows the diminishing return of productive hours as the regular workweek is extended to greater overtime. Th1s curve shows very little net increase in output beyond the 60-hour workweek. This decreased efficiency and high premium pay rates for overtime work lead to very high costs if the project must use regularly scheduled overtime to secure an adequate labor force.

The sensitivity of total plant cost to length of workweek, using the efficlency trends in Fig. 6.3 and double pay for all hours over 40 hours/ week, is shown in Fig. 6.4. Total plant costs increase about $0.8 \%$ for each hour increase in length of workweek.

\subsection{Lead Time}

Figures 6.5 and 6.6 illustrate the sensitivity of capital costs to length of design and construction period under two sets of assumptions. 




F1g. 6.2. Seneitivity of estimated power plant capital investment costa to construction labor requirements for 1990 operation. 

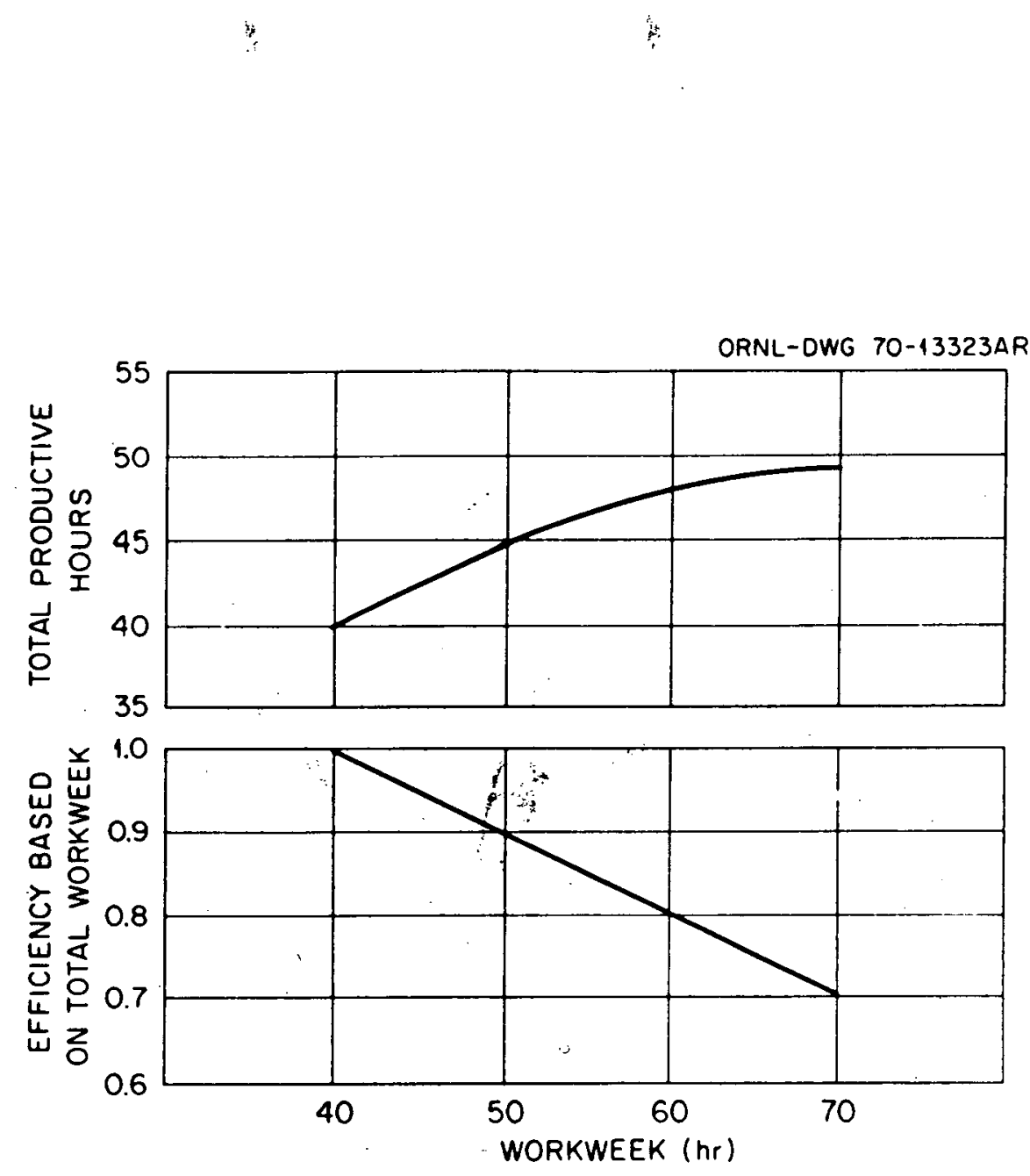

Fig. 6.3. Effects of sustalned overtime on productivity of construction labor. 


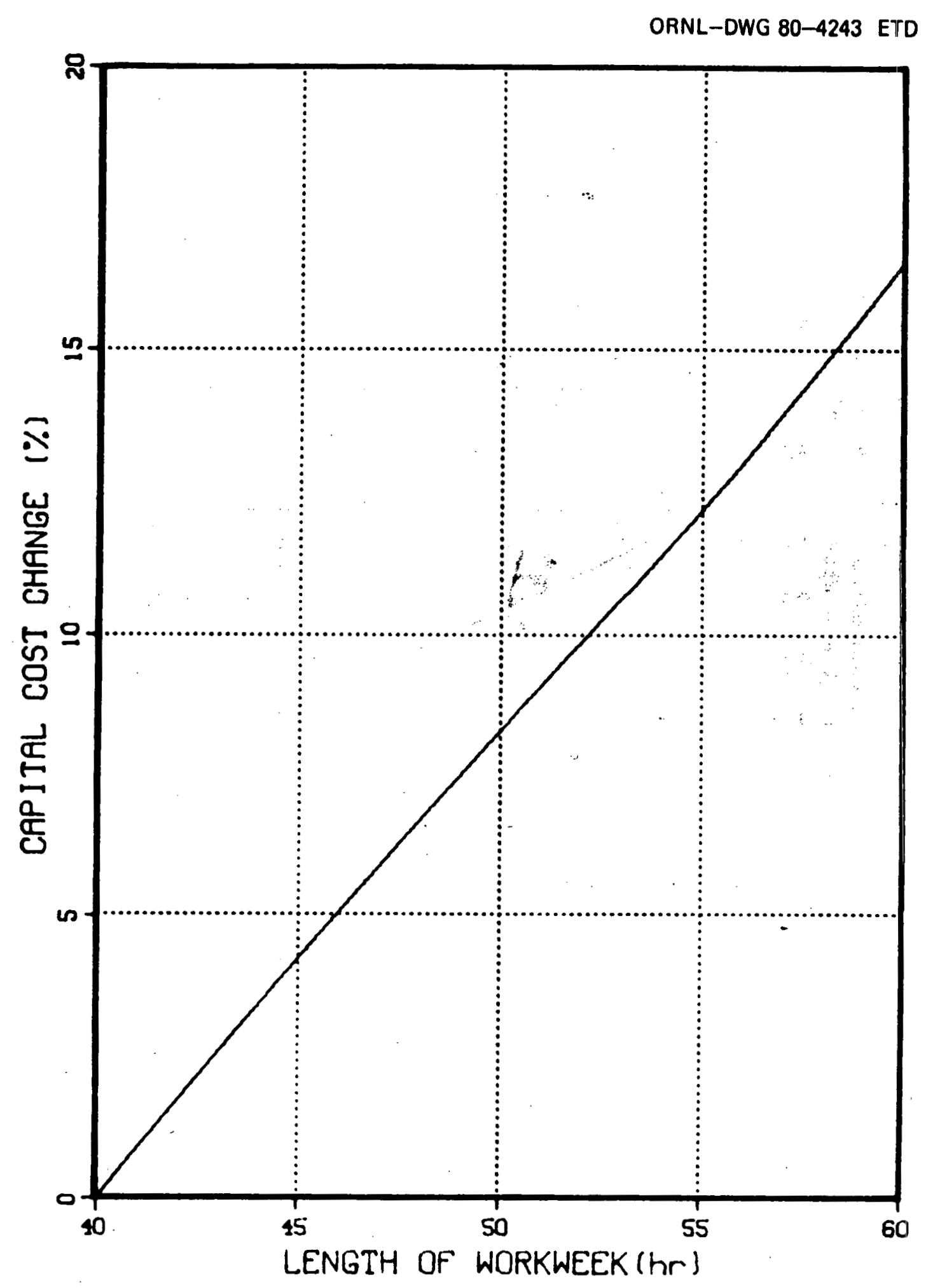

F18. 6.4. Sensitivity of estimated power plant capital investment costs to length of workweek for 1990 operation. 


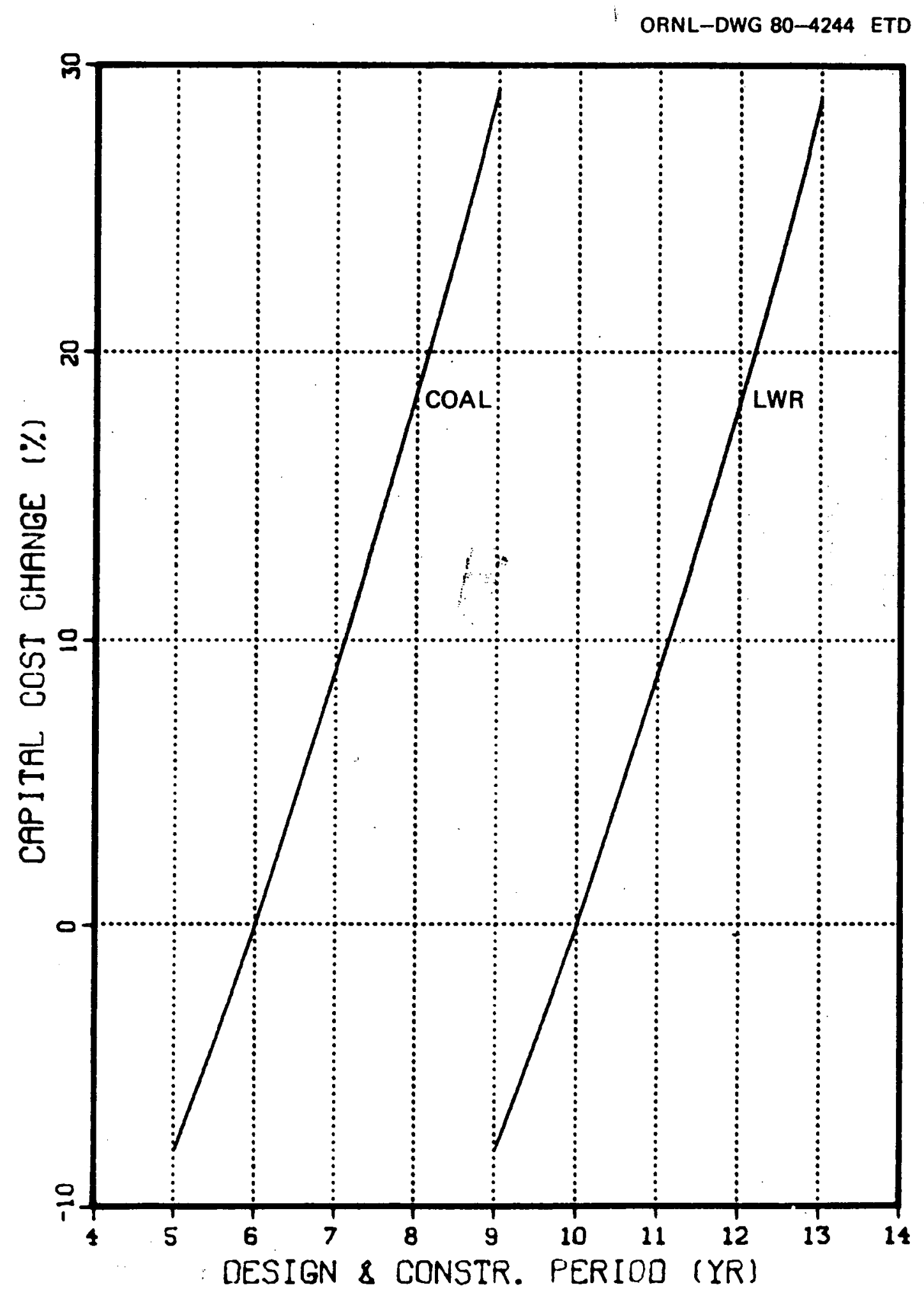

F18. 6.5. Sensitivity of estimated power plant capital 1nvestment costs to length of design and construction perlod with date of start of project constant. 


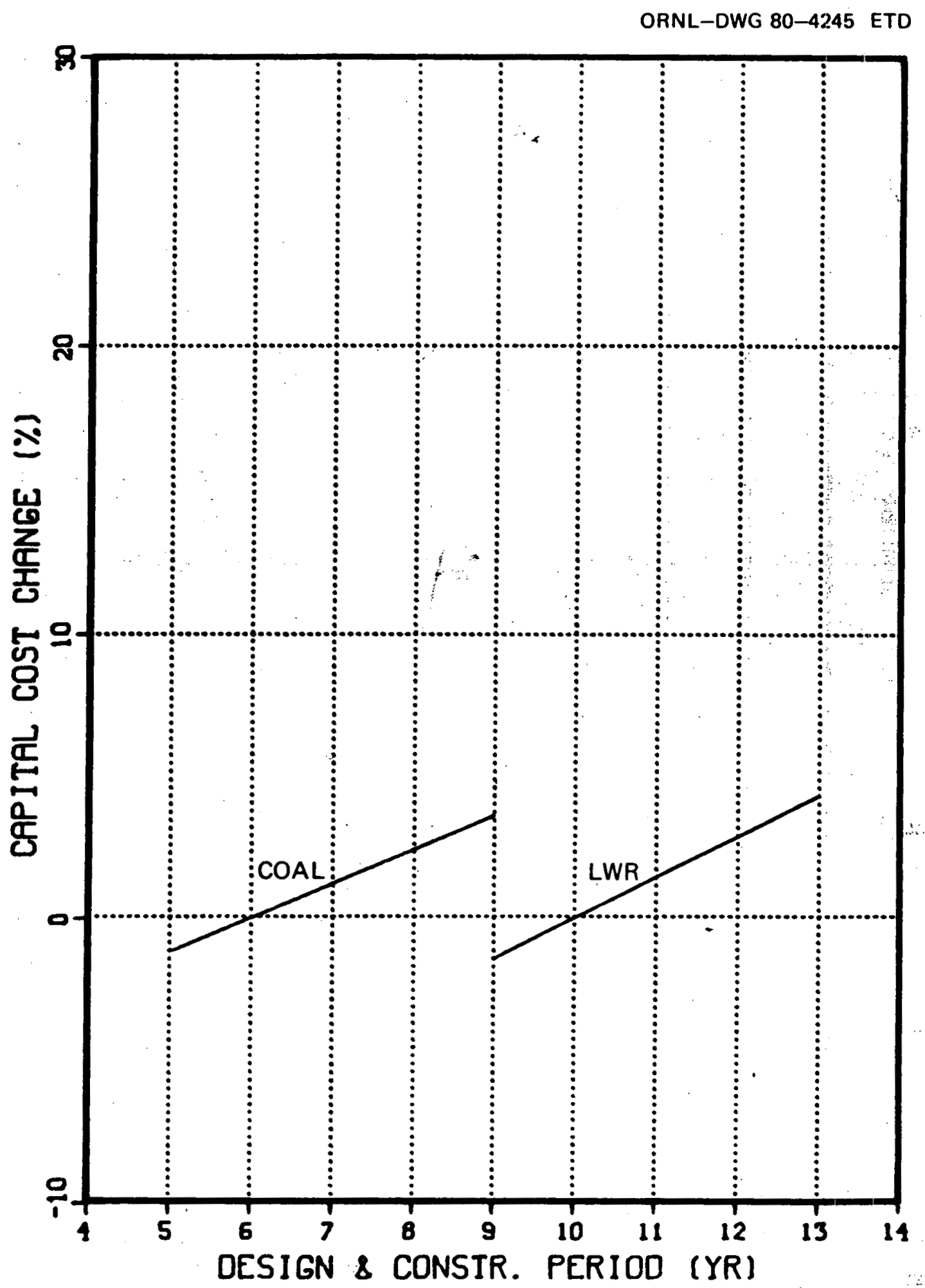

Fig. 6.6. Sensitivity of estimated power plant capital investment costs to length of design and construction period for 1990 operation. 
In Fig. 6.5 the year of steam supply purchase (or start of project) was held fixed while the design and construction period was varied, A oneyear change in design and construction period length under these conditions produces about $8 \%$ change in the total estimated cost of LWR and coal-fired plants. The cost changes are due to changes in cost of escalation and interest during construction, both of which increase as the design and construction period is lengthened.

In Fig. 6.6, the year of first commerclal operation is held fixed (1990) while the steam supply order date (start of project) and construction permit date are varied. Under these conditions cost is relatively insensitive to lead time. The curves of Fig. 6.6 would be horizontal if the interest rate and the escalation rate were 1dentical. The slight slope, about $1 \%$ change in total cost for each year change in design and construction period, results from an interest rate of $9.5 \%$ wh1ch exceeds the welghted average escalation rate of slightly over $7 \%$.

\subsection{Escalation}

Figure 6.7 11lustrates the effect of varying the overall escalation rate during design and construction on total estimated capital investment costs at first commerclal operation in 1990. The sensitivity of cost to escalation rate is quite pronounced. Since the coal-fired plant cash flow curve is later in time relative to the LWR, coal shows a higher relative escalation effect.

Figure 6.8 shows the sensitivity of estimated capital investment cost as year of first commercial operation is advanced or delayed. The curve in Fig. 6.8 was developed by varying year of first commerclal operation while maintainting a constant design and construction period of ten years for LWR plants and six years for coal-fired plants. Since the overall escalation rate used was $7.3 \% /$ year and $7.5 \% /$ year, respectively for LWR and coal-fired plants, costs double in approximately a 10-year time per1od. 


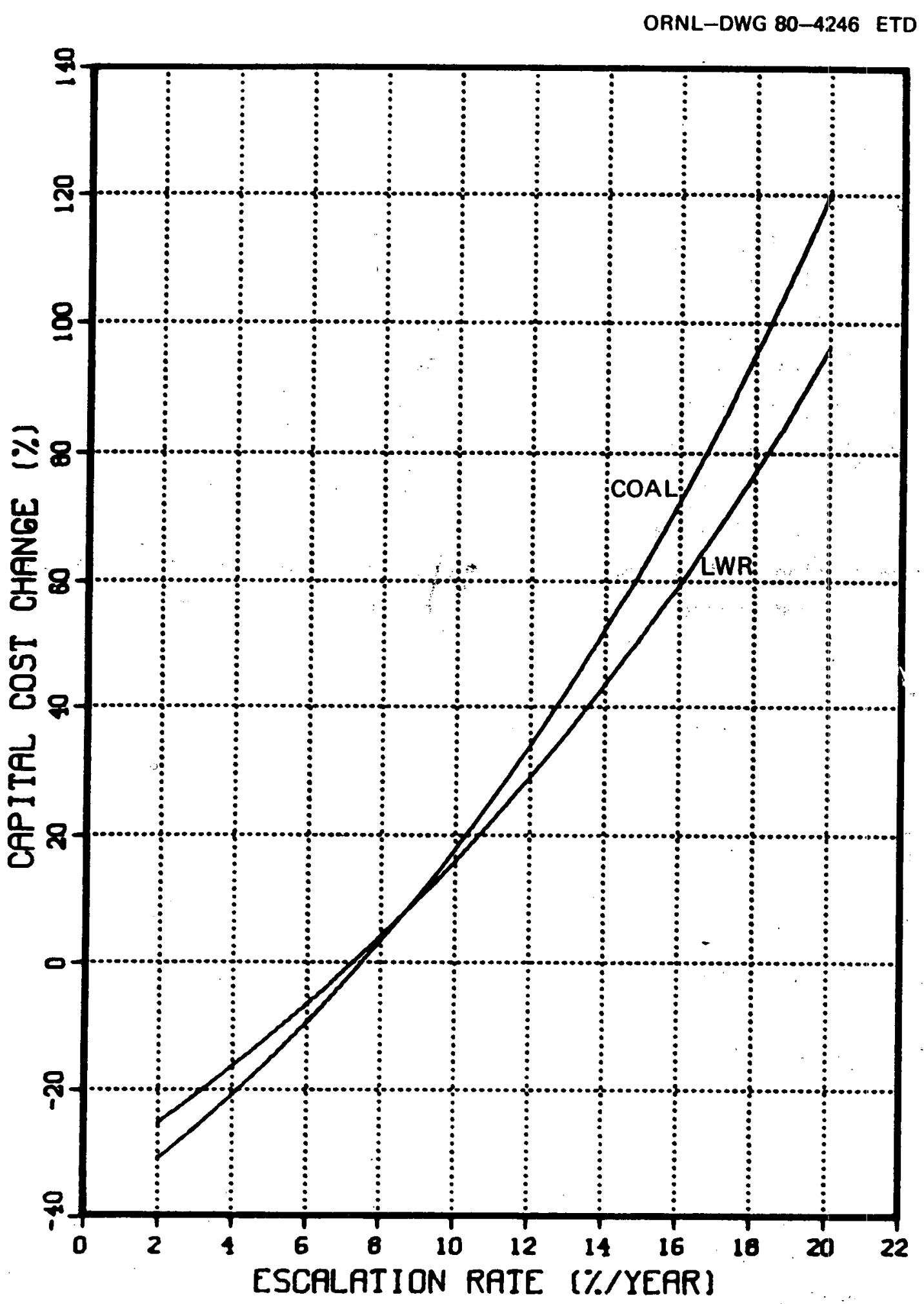

F1g. 6.7. Sensitivity of estimated power plant capital investment costs to escalation (or Inflation) rates for 1990 operation. 


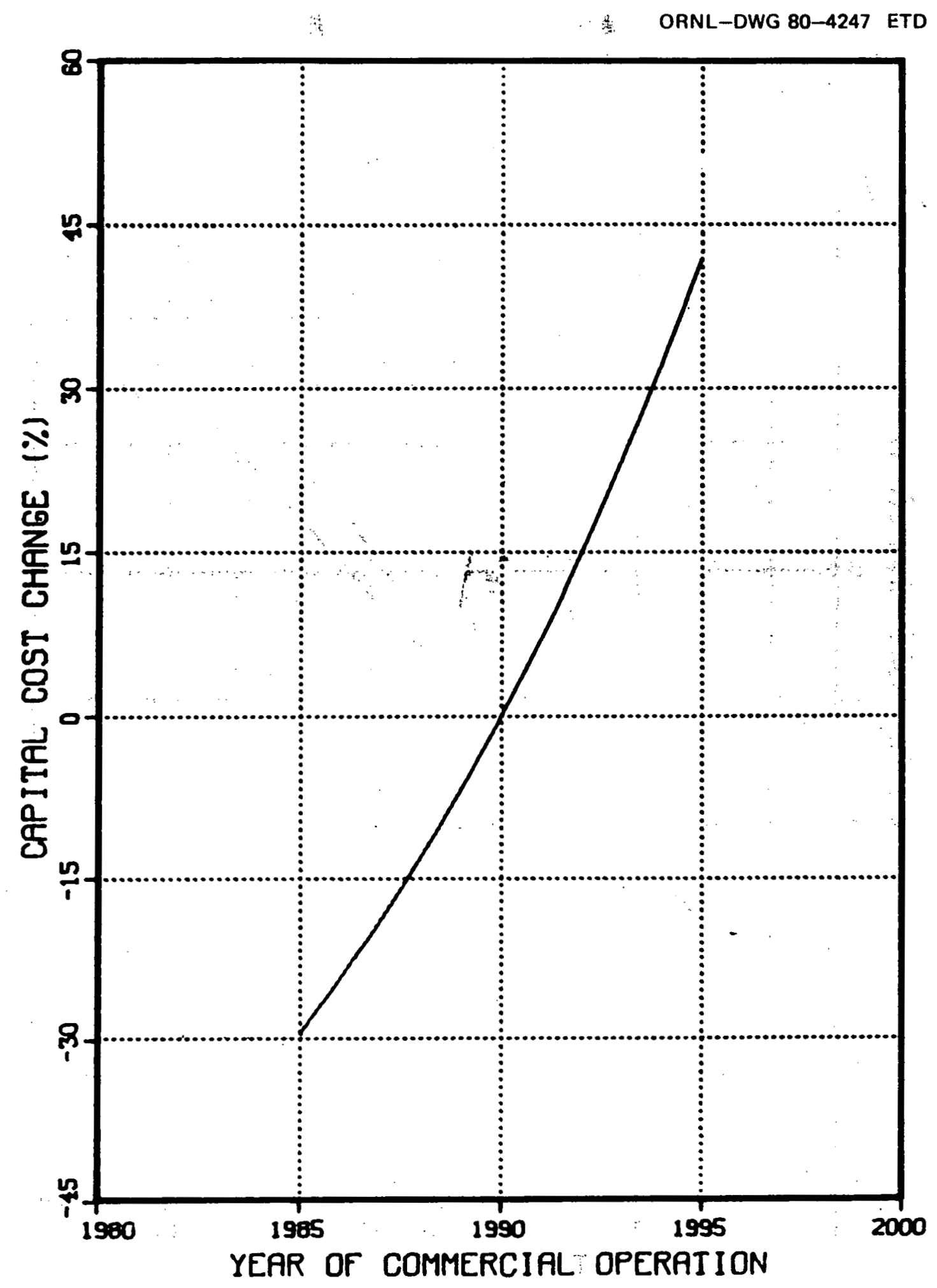

F18. 6.8. Sensitivity of estimated power plant capital investment costs to changing year of comerclal operation with constant escalation and length of design and construction perfod. 


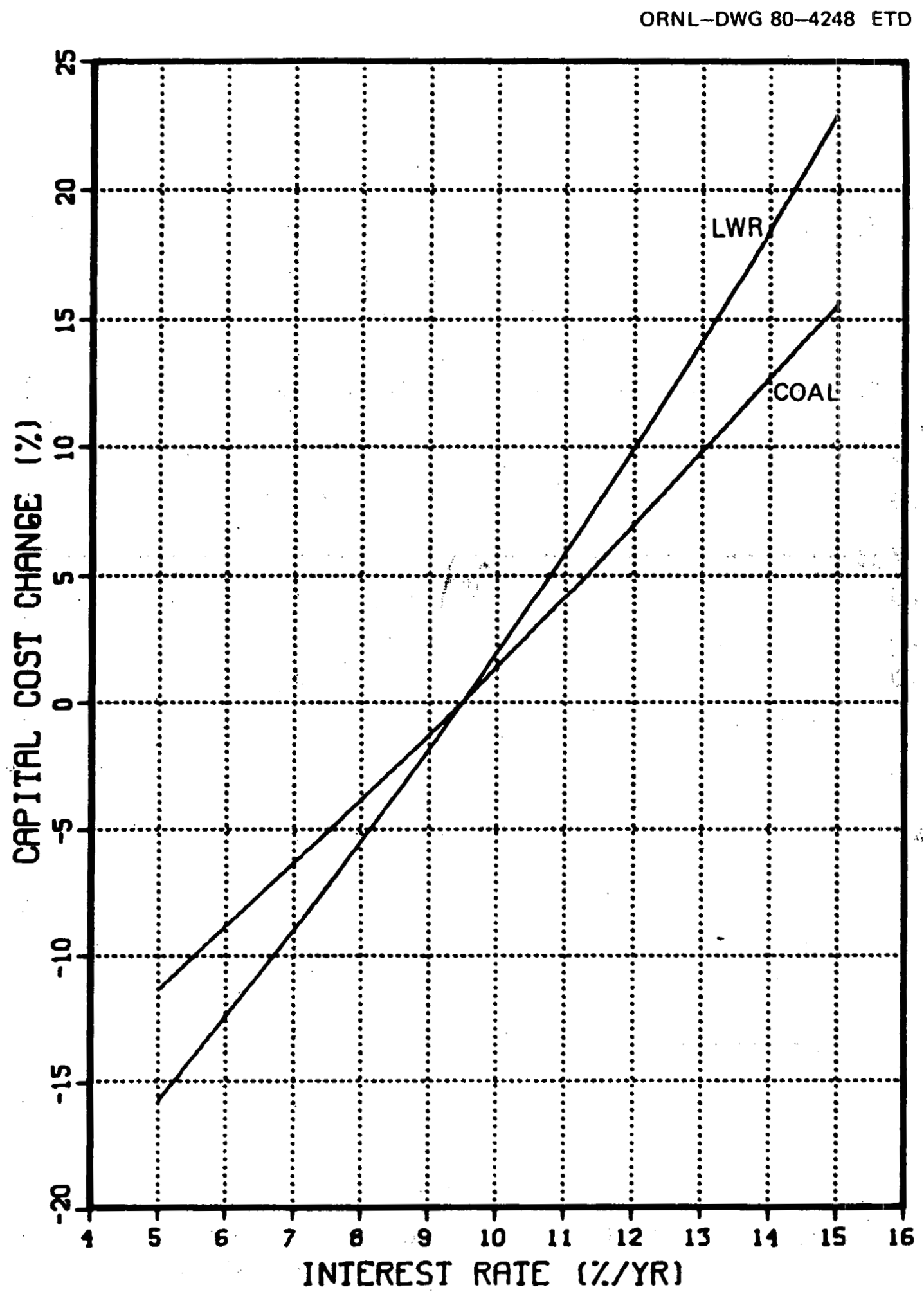

F1g. 6.9. Sensitivity of estimated power plant capital investuent costs to change in interest rate for 1990 operation. 


\subsection{Interest During Construction}

Investors in a utility must be compensated for the use of investment capital, both debt and equity, during the long perlod between the time funds for construction of the unit are spent and the time the unit goes into operation. Allowance for funds used during construction (AFUDC) is a charge made against construction work in progress to compensate these investors. During commercial operation the utility will recover from its customers through depreciation charges compensation for financing the investment made prior to operation. The FPC Uniform System of Accounts segregates AFUDC into two components, borrowed funds and other funds. CONCEPT utflizes a single rate referred to as the average annual interest rate during construction and allows treatment as simple or annually compounded interest.

The interest rate selected for úse in this study 9.5 percent per year compounded. As shown in Table 5.2 estimated interest during construction, or AFUDC, amounts to about $\$ 600$ milition for the $1139-\mathrm{MW}(\mathrm{e})$ LWR plant and about one-half that amount for the coal-fired plants. The smaller amount for the coal-fired plants is due to lower direct and indirect costs and shorter design and construction period.

Figure 6.9 shows the sensitivity of capital investment costs to change in the interest rate. LWR and coal-fired plant costs are estimated to change about $4 \%$ and $3 \%$, respectively, for each one percentage point change in interest rate. Coal-fired plant costs are less sensitive to changes in interest rates than LWR plant costs because of the shorter design and construction period.

\subsection{Regional Variations}

The CONCEPT code has access to cost-1ndex data files for 20 major locations in the Unfted States and two in Canada. The United States data were used to develop capital investment cost estimates for power plants as a function of location for January 1990 commercial operation, and the 
results are presented in Table 6.2. The variations in costs with location are due entirely to differences in site labor wage rates and est1mated costs of site materials such as structural steel, reinforcing steel, concrete, and lumber. The manufactured equipment cost data are the same for all cities. Transportation costs for major equipment, plant design features for the various geological and climatic conditions, and labor productivity differences from one area to another were not considered. Transportation costs for major equipment are relatively small. in the context of total plant costs, but plant design features for other geological and climatic conditions and labor productivity differences can have major effects on construction costs. The costs in Table 6.2 are lowest in the southern locations (BIrmingham, Dallas, New Orleans) and

Table 6.2 Regional vafiations in power plant capital invest ment cost estimates

for 1990 commercial operation

\begin{tabular}{lccc}
\hline Location & $\begin{array}{c}1139-\mathrm{MW}(\mathrm{e}) \\
\text { LWR }\end{array}$ & $\begin{array}{c}\text { 795-MW(e) } \\
\text { Coal }\end{array}$ & $\begin{array}{c}1232-\mathrm{MW}(\mathrm{e}) \\
\text { Coal }\end{array}$ \\
\hline Atlanta & 1620 & 1290 & 1170 \\
Baltimore & 1700 & 1350 & 1220 \\
B1 rmingham & 1590 & 1290 & 1150 \\
Boston & 1750 & 1390 & 1250 \\
Chicago & 1730 & 1410 & 1270 \\
Cincinnat1 & 1760 & 1420 & 1280 \\
Cleveland & 1730 & 1410 & 1270 \\
Dallas & 1580 & 1280 & 1160 \\
Denver & 1660 & 1310 & 1190 \\
Detroit & 1790 & 1450 & 1310 \\
Kansas C1ty & 1710 & 1360 & 1230 \\
Los Angeles & 1730 & 1440 & 1290 \\
Minneapolis & 1620 & 1320 & 1190 \\
New Orleans & 1570 & 1240 & 1120 \\
New York & 1770 & 1460 & 1310 \\
Philadelph1a & 1730 & 1410 & 1270 \\
P1ttsburgh & 1700 & 1380 & 1240 \\
St. Louls & 1690 & 1380 & 1250 \\
San Franclsco & 1760 & 1430 & 1290 \\
Seattle & 1750 & 1400 & 1270 \\
U.S. average & 1700 & 1370 & 1240 \\
Middletown & 1750 & 1420 & 1280 \\
\hline
\end{tabular}


highest in the northern and eastern industrialized areas (Detroit, New York, Cincinnat1) and on the West Coast (Los Angeles, San Francisco, Seattle).

Figures 6.10 and 6.11 show estimated power plant capital investment costs as a function of unit size, inftial commercial operation date, and location. For a given unft size and year of inftial commercial operation, the indicated range of costs results from locational variations in site-related materials and labor costs from the extremes of New Orleans (lowest) to Detrolt (highest). 
ORNL-DWG 80-424.9 ETD

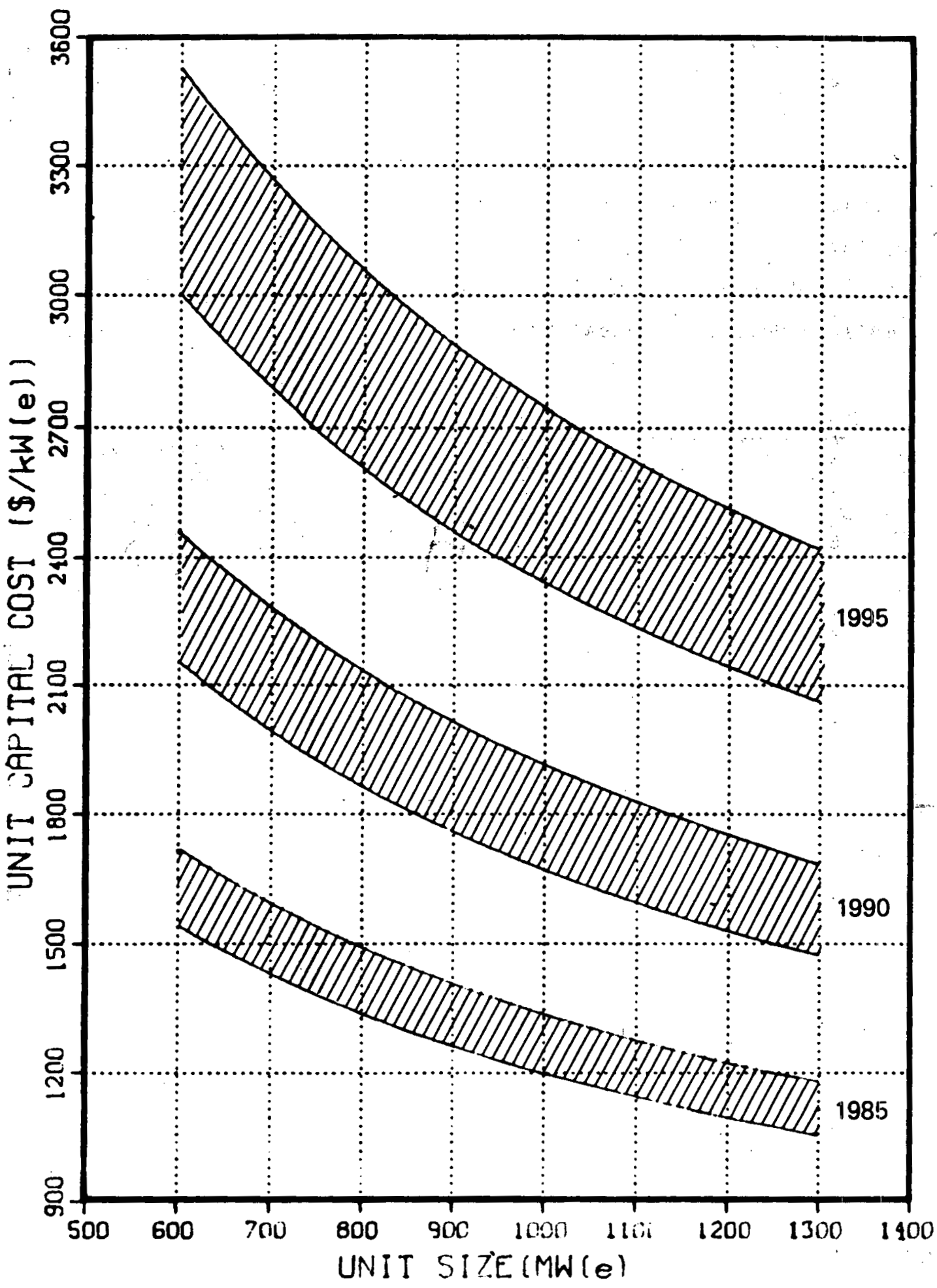

F18. 6.10. LWR power plant capital Investment cost estimates as a function of untt size, Inftial commerclal operation data, and location. 


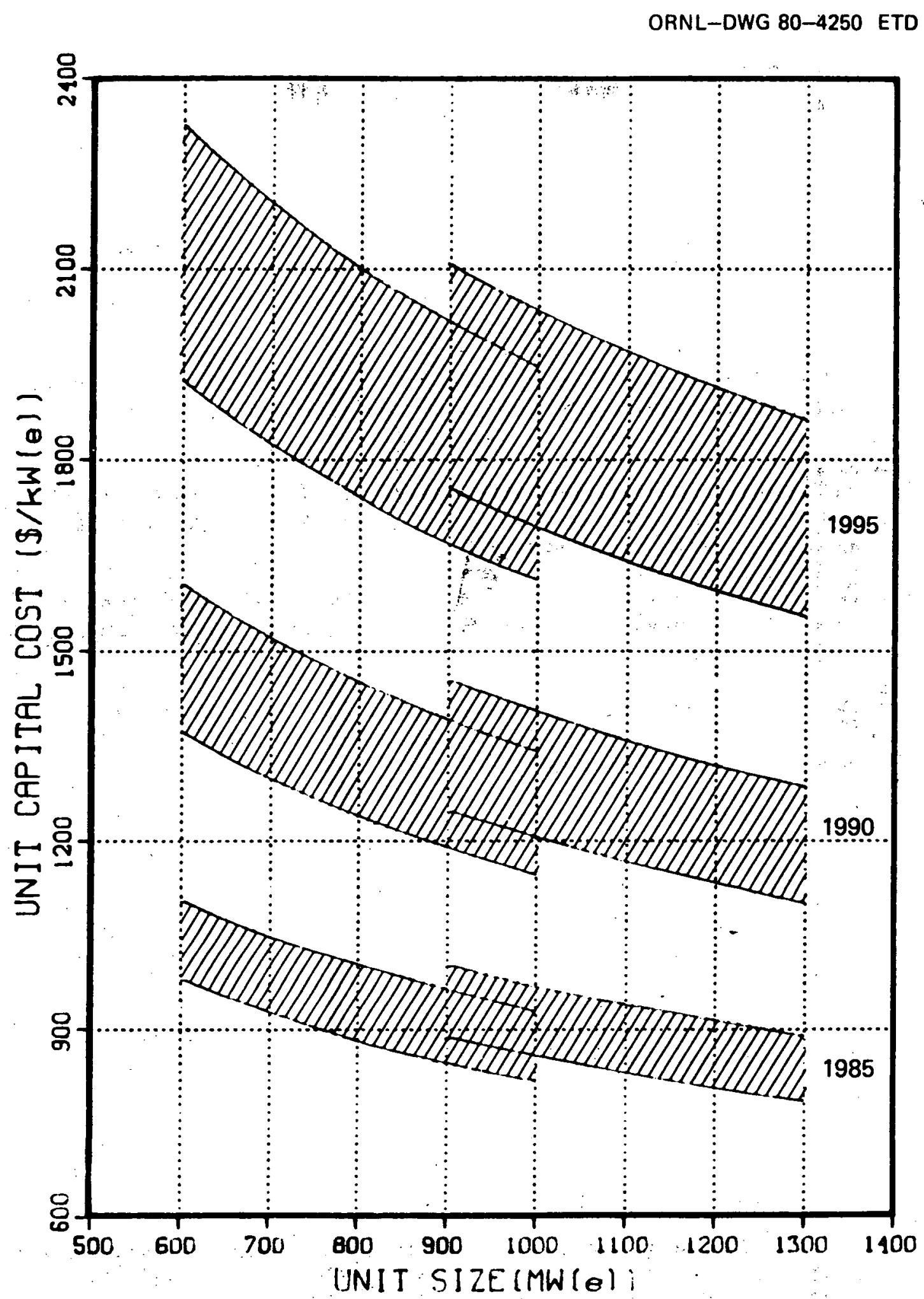

Fig. 6.11. Coal-fired power plant capital investment cost estimates as a function of unit size, inftial commercial operation date, and location. 


\section{REFERENCES}

1. U.S. Atomic Energy Commission, Current Status and Future Technical and Economic Potential of Light Water Reactors, WASH-1082, March 1968.

2. U.S. Atomic Energy Commission, Trends in the Cost of Light Water Reactor Power Plants for Utilities, WASH-1150, May 1970.

3. NUS Corporation, Guide for Economic Evaluations of Nuclear Reactor Plant Designs, NUS-531, January 1969.

4. United Engineers \& Constructors Inc., 1000 Me Central Station Power Plant Investment Cost Study, Pressurized Water Reactor Plant, WASH-1230 (Vol. I), June 1972.

5. United Engineers \& Constructors Inc., $1000 \mathrm{MWe}$ Central Station Power Plant Investment Cost Study, Boiling Water Reactor Plant, WASH-1230 (Vol: II), June 1972.

6. United Englneers \& Constructors Inc., 1000 MWe Central Station Power Plant Investment Cost Study, Coal-Fired Fossil Plant, (Vol. III), June 1972.

7. United Engineers \& Constructors Inc., 1000 MWe Central Station Power Plant Investment Cost Study, Oil-Fired Fossil Plant, WASH-1230 (Vol. IV), June 1972.

8. U.S. Atomic Energy Commission, Power Plant Capital Costs Current Trends and Sensitivity to Economic Parameters, WASH-1345, October 1974.

9. United Engineers \& Constructors Inc., Commercial-Electric Power Cost Studies - Capital Cost: Pressurized Water Reactor Plant, NUREG-0241 (co0-2477-5), June 1977.

10. United Eng1neers \& Constructors Inc., Commercial Electric Pouer Cost Studies - Capital Cost: Boiling Water Reactor Plant, NUREG-0242 (CO0-2477-6), June 1977.

11. Un1ted Engineers \& Constructors Inc., Commercial Electric Power Cost Studies - Capital Cost: High and Low Sulfur Coal Plantes - 1200 MWe, NUREG-0243 (C00-2477-7).

12. Unfted Eng1neers \& Constructors Inc., Commercial Electric Power Cost Studies - Capital Cost: Low and High Sulfur Coal Plants $-800 \mathrm{MWe}$, NUREG-0244 (COO-2477-8).

13. United Englneers \& Constructors Inc., Commercial Electric Power Cost Studies - Capital Cost Addendum: Multi-Unit Coal and Nuclear Stations, NUREG-0245 (C00-2477-9). 
14. United Engineers \& Constructors Inc., Commercial Electric Power Cost Studies - Fuel Supply Investment Cost: Coal and Nuclear, NUREG-0246 (CO0-2477-10), April 1979.

15. United Eng1neers \& Constructors Inc., Commercial Electric Power Cost Studies - Cooling Systems Addendum: Capital and Total Generating Cost Studies, NUREG-0247 (C00-2477-11), September 1978.

16. United Engineers \& Constructors Inc., Commercial Electric Power Cost Studies - Total Generating Costs: Coal and Nuclear Plant6, NUREG-0248 (C00-2477-12), February 1979.

17. United Engineers \& Constructors Inc., Commercial Electric Power Cost Studies - Capital Cost Pressurized Heavy Water Reactor Plant, co0-2477-13, June 1977.

18. United Engineers \& Constructors Inc., Capital Cost: Gas Cooled Fast Reactor Plant, co0-2477-16, September 1977.

19. U.S. Atomic Energy Commission, CONCEPT, A Computer Code for Conceptual Cost Estimates of Stecon-Electric Power Plants - Status Report, WASH-1 180, April 1971.

20. R. C. Delozier, L. D. Reynolds, and H. I. Bowers, CONCEPT Computerized Conceptual Cost Estimates for Steam-Electric Power. Plants - Phase I User's Manual, ORNL/TM-3276, October 1971

21. H. I. Bowers et al., CONCEPT - Computerized Conceptual Cost Estimates for Steam-Electric Power Plants - Phase II User's Manual, ORNL-4809, April 1973.

22. U.S. Energy Research and Development Administration, CONCEPT A Computer Code for Conceptual Cost Estimates of Steam-Electric Power Plants - Phase IV User's Marual, ERDA-108, June 1975.

23. C. R. Hudson, User's Instmution for Preliminary Version of the CONCEPT-5 Computer Code, ORNL TM-6230, February 1978.

24. C. R. Hudson II, CONCEPT-5 User's Mamal, ORNL-5470, January 1979.

25. U.S. Department of Labor, Bureau of Labor Statistics, Monthly Labor Review, published monthly.

26. U.S. Department of Labor, Bureau of Labor Statistics, Employment and Eamings, published monthly:

27. U.S. Department of Labor, Bureau of Labor Statist1cs, Producer. Prices and Price Indices, Washington, D.C., published monthly. 
28. U.S. Department of Labor, Bureau of Labor Statist1cs, National Survey of Professional, Adminstrative, Technical and Clemical Pay, Washington, D.C., published annually.

29. Engineering New6-Record, McGraw-Hil1, New York, publlshed weekly.

30. C. G. Lindeman and R. E. Hope, "Reducing Construction Costs," pp. 292-303 In 1969 Transactions of the American Society of Cost Engineers, American Society of Cost Engineers, 1969.

31. N. D. Jacobs, "SACCS: New Control Tool for Power Plant Construction Scheduling and Costs," Heat Engineering, Foster-Wheeler: Corporation, November-December 1969, pp. 66-73.

32. A. B. Lorenzonf, "Productivity-Everybody's Business", Cost: Engineering, Vo1. 21, No. 5, September-Octor-. '979, pp. 189-192. 